\title{
IGNACIO DE HEREDIA \\ Y SU BIBLIOTECA
}

\author{
Rafael OLAECHEA
}

Universidad de Zaragoza

SUMARIO:

- Los Heredia de Graus (Huesca).

- Ignacio de Heredia y Alamán.

-Algunos rasgos psicológicos de Heredia.

-El funcionario Heredia y su veta de «ilustrado».

- Heredia en París.

- Misión de Heredia en Londres.

-De nuevo en París.

- Servicios ocultos de Heredia.

-Regreso de Heredia a España: su paso por Graus.

-La "librería" de Ignacio de Heredia. 
El conde de Aranda, alejado de Madrid por intrigas del marqués de Esquilache, ministro a la sazón de Hacienda y de Guerra, fue nombrado capitán general de los reinos de Valencia y Murcia, y en marzo de 1764 se presentó en la ciudad del Turia acompañado de su secretario particular don Ignacio de Heredia y Alamán.

El 27 de marzo de 1766 llegó a la capital valenciana un correo extraordinario con la noticia de que el día 23, Domingo de Ramos, habia estallado en Madrid un terrible motín contra el marqués de Esquilache. Diez y siete años más tarde, escribiendo Aranda a Heredia, que se hallaba en Londres, le decía con un juego de frases bilingües: "De Madrid me dice mi mujer, con fecha del jueves 27 de marzo, y su acostumbrado claro estilo [...], que el lunes 24 (époque des articles populaires) el Sr. Figueroa pasó al Pardo, y en el cuarto del Sr. Múzquiz tuvo un baidillo [sic]. Que el martes 25 (époque du grand jour des mutins) se restituyó a su casa. Que el miércoles 26 lo pasó con ahogos al pecho, y en el día de la carta por la tarde lo sacramentaron (époque du courier arrivé à Valence, et de la mauvaise nuit que $\mathrm{Mr}$. le Chevalier d'Heredia passa, avec la joie d'une certaine personne lui interrompant son sommeily(1), burlica burlando hace de eso 17 años.

"Graus y Siétamo, al principio de ellos, dieron al reino la paz interna, y a su fin la externa(2), sin que se pueda decir que en ambas ocasiones hayan hecho sino lo que sus chollas les dictaron, ni se hayan mezclado otros factores $x(3)$.

Como puede verse, la confianza entre ambos aragoneses era ya grande en Valencia, sin que las distancias protocolarias (4) les quitaran libertad para gastarse bromas y decirse las cosas "a la baturra».

Ignoramos la fecha exacta en que se conocieron Aranda y Heredia, pero tampoco hace mucho al caso. Lo que en cambio resulta cierto es que, mientras la Junta Militar, presidida por el conde, celebraba sus sesiones a lo largo del año 1763(5), Aranda vió con frecuencia-y acaso pensó entonces en tomar como secretario suyo-a su paisano Heredia, quien, desde mayo de 1757, trabajaba como "covachuelista" en la Secretaría de Gracia y Justicia, a las órdenes del ministro titular don Alfonso Múñiz, marqués del Campo de Villar. 
Los Heredia eran una de las muchas familias infanzonas del reino de Aragón, y su escudo heráldico estaba representado por cinco castillos de plata sobre campo de terciopelo rojo. A fines del siglo XV, Martin de Heredia salió de Murcia, y después de rondar años y leguas acabó estableciéndose en la villa de Graus(6). De su matrimonio con Jerónima Español nacieron dos hijos: José, el menor, y Miguel, el primogénito, que en 1568 casó con Magdalena Hernández de Diago. A partir de esta fecha se conoce documentalmente la genealogia de los Heredia(7), pero no bajaremos de rama en rama por los entronques de tan frondoso árbol.

Para lo que aquí nos interesa, baste decir que José Rodrigo de Heredia y Estanga, carlán(8) de Güel, señor de Penilla, y abuelo paterno de nuestro Ignacio, fue requerido por el delfín Felipe de Anjou, nieto de Luis XIV, a ocupar un escaño en las Cortes de Zaragoza, que se abrieron el 3 de noviembre de 1701 bajo la presidencia del pretendiente francés, futuro rey de España con el nombre de Felipe V(9). Esto no obstante, los avatares de la ruinosa "Guerra de Sucesión de España" (1700-13), hicieron que en noviembre de 1708 le fuera conferido a José Rodrigo el comprometido cargo de "Comisario General de Guerra en el Reino de Aragón» por el mismo archiduque Carlos de Austria(10), a quien muchos aragoneses, al igual que algunas instituciones de dicho reino(11), miraban con mayor simpatía que a su rival Felipe $V$ en sus pretensiones al trono de España.

Todavia el 28 de febrero de 1713, el archiduque Carlos, siendo ya emperador de Austria, volvió a confirmar a José Rodrigo de Heredia en el cargo de "Comisario General de la Gente de Guerra del Reino de Aragón", porque, durante aquellos cinco años de dura contienda, el Consejo de Aragón no le había expedido el asiento correspondiente, ni él había entrado nunca en el goce del sueldo que le correspondía, desde 1708, por ejercer el referido cargo'12).

De su matrimonio con Jerónima Subiza y Pórtola(13) le nacieron a José Rodrigo tres hijos(14), el menor de los cuales, Juan Francisco, fue el heredero de un mayorazgo patrimonial sensiblemente mermado, no sólo por las secuelas y exigencias de una larga guerra civil, en la que su padre había luchado durante años "gratis et amore", sino por las multas que el vencedor Felipe $V$ impuso a los rebeldes aragoneses, partidarios de su rival el archiduque austriaco Carlos. 
Juan Francisco de Heredia y Subiza, que era carlán de Besiáns y señor de Penilla, se casó en 1727 con Antonia Alamán Cavero, natural de la villa de Naval (Huesca), la cual aportó al matrimonio una pingüe dote, gracias a la cual pudo restablecerse en parte el antiguo nivel económico de la familia Heredia(15).

Ocupando uno de los lados de la plaza principal de la villa de Graus se halla la casa solariega de los Heredia. Forman su fachada principal una doble fila de balcones cortados, y unos frescos pintados en los entrepaños. Los muros son de piedra de sillería; un alero saledizo, con vigas talladas, hace como de visera de la amplia fachada, y entre muñón y muñón de las vigas se puede ver (se podia ver en 1954, año de mi última visita) una serie de pinturas que representaban la historia o parábola evangélica del «hijo pródigom.

\section{IGNACIO DE HEREDIA Y ALAMAN}

En esta casa espléndida, de ancha portalada y porche señorial, vino al mundo Ignacio de Heredia y Alamán el 31 de agosto de 1728, y sus padres, que eran muy "afectos" a los jesuitas, le pusieron el nombre del santo fundador de la Compañía de Jesús. Nuestro héroe fue el primero de los ocho vástagos que tuvo doña Antonia Alamán(16), y creció, a la sombra de sus padres, en el seno de una familia sólidamente cristiana, y económicamente abastada, aunque políticamente "austracista", esto es: monárquica, pero antidinástica, quiero decir: no borbónica.

Graus tenía entonces unos dos mil habitantes(17), y gran parte de la infancia graense aprendia las primeras letras y algo de humanidades en el colegio que la Compañía de Jesús regentaba en aquella localidad. El Colegio de San Francisco Xavier, que así se llamaba, habia sido abierto el verano de 1652, durante el generalato del P. Goswino Nickel (1652-1664), siendo su alma y verdadero fundador del obispo de Huesca, don Esteban Esmir, natural de Graus, quien suministró veinte mil ducados para instalar dicho colegio con un mínimo de comodidades, pues todo el dinero con que contaban los fundadores iniciales se lo había llevado la construcción de los muros y cimientos de aquel destartalado caserón. Si atendemos a los 
comentarios de algunos jesuitas de entonces, parece que no era nada envidiable ser destinàdo al "colegio ribagozano de Graus", ya que lo tenian como el "destierro de la provincia jesuítica de Aragón", y, de hecho, en calidad de tal fue escogido en 1658, cuando se destinó allí, durante unos meses, al autor de El Criticón(18). Esto no obstante, los vecinos de Graus-empezando por los Heredia, para no hablar de los Bardaji-estaban orgullosos de poseer aquel centro de educación, y algunas familias tenian a gala el ocupar la presidencia del patronato de dicho colegio.

Por aquel centro pasó Francisco Xavier, el menor de los Heredia, que más tarde se hizo jesuita, y en 1767 salió desterrado de España, cuando Carlos III expulsó de sus dominios a la Compañía de Jesús(19). Antes que él se había sentado en las mismas aulas su hermano mayor, Ignacio, que perteneció a la Congregación Mariana de dicho Colegio, y acaso por eso, o porque durante algún tiempo mostró cierta inclinación hacia el estado clerical, con veleidades de ingresar en la Compañia de Jesús, el conde de Aranda le solía Ilamar irónicamente "don Iñigo de Guipúzcoa», cuando no le daba el apelativo de "caballero de la Virgen»(20).

Terminada la primera enseñanza en Graus, unos pocos privilegiados solían partir para otros lugares, con objeto de ampliar sus conocimientos. La ciudad de Huesca era entonces uno de los principales centros de polarización de la población estudiantil altoaragonesa. Gran parte de los jóvenes que habian estudiado latinidades en otros centros inferiores, pasaban a la "Universidad y Estudio General de Huesca" (a la que también se le daba el nombre de Universidad Sertoriana), y en ella cursaban los estudios de Teología, Sagrada Escritura, Cánones, Medicina, Leyes y Filosofía o Artes. El número de estudiantes oscilaba, según los cursos, entre 400 y 500 , destacando por su mayoría los teólogos y los legistas(21).

Ignacio de Heredia, decidido a seguir la carrera clerical-ya que no la de jesuita-, se matriculó en la Universidad de Huesca el curso 1744-45, para estudiar el Bachillerato en Artes, que duraba cuatro años, y a los diez y seis años de edad se ospedó en el Colegio de San Vicente, anexionado a la Universidad desde 1669, después de obtener en él una plaza (cosa por lo demás nada fácil), gracias a la recomendación del obispo de Barbastro, don Carlos de Alamán, tío abuelo suyo por parte de madre, y antiguo colegial de aquel centro. 
Los Estatutos de la Universidad de Huesca, promulgados en 1721, habian establecido la golilla como vestido uniforme para los estudiantes de la Sertoriana; y ordenaban que todos llevaran «sotana sin profanidad de colas" ni otros adornos de ostentación, so pena de cuatro sueldos de multa por la primera infracción, y de diez y seis en caso de reincidencia. También se recomendaba el uso de zapato llano y sin tacones, porque éstos hacian "muy indecente la modestia de los hábitos»(22).

El año 1748, Heredia se matriculó en la Facultad de Derecho Canónico, para obtener el Bachillerato de Cánones. Ningún estudiante podía presentarse a él si antes no había cursado los estudios de Latinidad, y alcanzado el Bachillerato en Artes(23). Como pupilo del Colegio de San Vicente, Heredia preparó el Bachillerato en Cánones, que también duraba cuatro cursos, cada uno de los cuales tenía un mínimo de «seis meses más un dia» de escolaridad.

Durante estos años, el joven Ignacio conoció a otros estudiantes de porvenir. Por aquel patio octogonal de treinta y dos columnas, centro de la circulación universitaria oscense, había pasado, y todavía pasaría, una pléyade de estudiantes preclaros-incluido el ministro Calomarde-, hasta que la Sertoriana se cerró definitivamente en 1845. Precisamente en 1749 termino su Bachillerato en Leyes otro ilustre colegial de San Vicente. Me refiero al barbuñalés José Nicolás de Azara (1730-1804), quien después de fracasar en las oposiciones de Digesto Viejo, pasaria a Salamanca como pupilo del colegio mayor de San Salvador de Oviedo(24).

Terminado su Bachillerato en Cánones a los 24 años de edad, Heredia recibe el 16 de junio de 1752 la tonsura clerical, de manos de don Juan Ladrón de Guevara, obispo de Barbastro, en la capilla del palacio episcopal de esta localidad(25).

La tonsura clerical era, de hecho y de derecho, el primer paso indispensable hacia el sacerdocio, pero uno se pregunta si el perpetuamente célibe Ignacio de Heredia tenía verdaderos deseos de ordenarse de sacerdote, o si sus designios a este respecto no eran sino otras tantas veleidades «in fieri». $Y$ es que, en rigor, Heredia no necesitaba, o no le hacia falta, el Bachillerato en Cánones para recibir el presbiterado, y en lugar de haberse graduado en esta materia hubiera podido cursar, durante el mismo cuadrienio, los estudios de Teología, que sí le eran imprescindibles para 
subir al altar. Pero ni antes de la tonsura, ni después de haberla recibido se dedico al estudio de esta disciplina, antes bién continuo avanzando por el camino canónico, con ánimo de doctorarse en esta facultad. Por otro lado, resulta un tanto desconcertante el hecho de que Heredia no se tonsuró con la mira de entrar en posesión de alguna renta eclesiástica, como era el caso de tantos jóvenes coetáneos suyos, porque él nunca disfrutó de este tipo de sinecuras. Entonces-se pregunta uno-, ¿por qué razón, o con qué fin, recibió la tonsura?.

No sabemos-documentalmente-si Heredia llegó a doctorarse en Derecho Canónico, pero existen algunos testimonios de peso que permiten afirmar este hecho(26). El conde de Fernán Núñez, que conoció a Heredia en París el año 1775, encargaba desde la capital francesa al conde de Aranda, establecido ya en Madrid, que saludara de su parte al doctor Heredia(27); y en el "Libro Ceremonial de la Sertoriana Universidad de Huesca" se dice escuetamente, refiriéndose a la convocatoria de cierto exámen, y al correspondiente tribunal examinador: "En 17 de julio de 1755, se examinó de Bachiller en Cánones el Sr. Obispo de Tarazona [Esteban Vilanova Colomer]. En 21 de julio tuvo lugar la presentación. Examinadores: D. Martín Lorés, $D$. Ignacio de Heredia, y D. José Tolosana. De Decretales, leyó el candidato del capítulo "De sententia et re iudicata". Electores: D. Pedro López y D. Bernardo Oliván»(28).

Este dato tiene un valor testimonial, porque los Estatutos de la Universidad de Huesca ordenaban que el candidato al Bachillerato de cualquiera de sus Facultades, debía realizar el examen a este grado ante un tribunal compuesto exclusivamente por doctores, y en calidad de doctor en cánones tomó parte Heredia en dicho acto académico.

La falta de elementos documentales nos impide determinar, con exactitud la fecha y los motivos por los que nuestro héroe dio un golpe de timón a la dirección de su vida, y, en este sentido, toda suposición, por sensata que fuera, no pasaria de ser una especulación gratuita. Lo único que puede asegurarse es que Ignacio de Heredia-tonsurado y doctor en cánones-abandonó para siempre, tanto el camino del sacerdocio, como sus actividades docentes en la Universidad Sertoriana, y en abril de 1757 pasó a vivir a Madrid(29). 
Por desgracia, tampoco tenemos datos fehacientes que nos hagan conocer, con certeza histórica, si tal mutación afectó-y en qué grado pudo afectar-la psicología y el comportamiento de este hombre, que siempre dio al exterior muestras de ser un tanto poltrón, e incluso un egocéntrico, pues el propio Aranda solía llamarlo a veces «don Ego»(30).

Por razones de claridad, y para dar coherencia a nuestra exposición, nos veremos obligados a repetir más tarde que Aranda fue nombrado en 1773 embajador de España en París, a donde se dirigió en compañía de su fiel secretario Heredia. Pues bien, tuvieron que transcurrir diez años, a partir de esa fecha, antes que Carlos III concediera al conde permiso para pasar unas semanas en España. Durante su ausencia, Heredia quedó al frente de la embajada(31).

Aranda emprendió su viaje el 10 de diciembre de 1783, sin preocuparse de los frios invernales, y al llegar a Jadraque (Guadalajara) se enteró de que su fiel esposa, doña Ana Maria del Pilar Fernández de Hijar, había fallecido en Madrid el 24 de ese mismo mes. Pronto se consoló el conde de semejante pérdida, pues el 14 de abril de 1784 se casó en segundas nupcias con M. a Pilar Fernández de Hijar y Palafox, joven de 17 años de edad(32). El conde, que frisaba los 65 años, estaba evidenternente urgido por la necesidad de dar un heredero a la Casa de Aranda.

La noticia de esta boda se extendio-para usar una metáfora original- "como un reguero de pólvora", y Aranda recibió una infinidad de plácemes y enhorabuenas. Uno de los que con más sinceridad y efusión le felicitó fue el asturiano don Alvaro de Navia, vizconde de la Herrería, el cual le escribió desde Nápoles, donde estaba de embajador de España, las siguientes líneas: "En las cartas del 9 y 30 de marzo me dice V. E. cuanto le ocurrió de infausto desde Irún adelante, cuánta dicha le esperaba desde el 14 de abril en adelante, y las disposiciones que tomaba $V$. E. para su alojamiento en Paris y el de nuestra nueva dignisima embajadora, y no tiene duda de que VV. EE. estarán à ravir en la plaza de Luis XV.

Sé todas las buenas circunstancias de la Sra. Novia, su buena figura, su talento, su agrado y su representación. Tampoco Xaviera [mi mujer] lo ignora, y me encarga que dé a $V$. E. millones de enhorabuenas, añadiéndole yo que jamás hay riesgo de echarse a plomo sobre un buen colchón, siendo tan buenos los instrumentos operarios, como se supone [son] los 
de la Botica de V. E., de cuya oficina se proveía lo ordinario y [lo] extraordinariox(33).

Mientras la nueva pareja hacía los preparat ivos de su viaje de regreso a Paris, Aranda escribía a Heredia dándole indicaciones sobre su llegada a la embajada. En una de estas cartas le decía: "Señor comodón: la joven Embajatriz, en comiendo, se hará la desentendida, para que VS vaya a su siesta sin ponerse de mal humor por retardársela. Quedo enterado de los cálculos de VS sobre su regreso a España, y siempre dispuesto a idear todo lo que pueda incomodarle menos. Esto se llama tener buen almaw(34).

Como puede apreciarse, la campechanía con que se trataban Aranda y Heredia era muy grande, y el secretario comía siempre en la misma mesa que su jefe el embajador. Es, pues, muy comprensivo que, al evocar juntos antiguas vivencias, Heredia contara al conde los motivos que le habian inducido a cambiar la trayectoria de su vida, y a dejar Huesca para trasladarse a Madrid. El caso es que en 1784, es decir, a los 28 años de darse esta mutación, Aranda seguía bromeando a su secretario con la canción de la clerecía, y de su recalcitrante celibato, como dando a entender que aún seguía haciéndole gracia la circunstancia de que este Heredia, de París, hubiera podido acariciar, en alguna época de su vida, la idea de hacerse sacerdote.

Por eso, recordando esta veleidad del "caballero de la Virgen", Aranda le comunicaba desde Madrid que pensaba llevar a París a su mujer, "dama moza", para "dar dentera y hacer rabiar al señor Colegial de San Vicente", si bien le permitiria que use fuera con ella del brazo a pasear por las Tullerías [sic]w(35). Y como Heredia insistiera en que proyectaba irse a Madrid, a ocupar su plaza de Consejero de Guerra, el conde le respondió diciéndole: "Es ya público que se casa la viuda de Rojas con el conde de Asalto, y así no piense VS más en ella; pero al venirse aquí, pásese por Barcelona, donde dicha Señora piensa establecerse, para reconvenirle por haberse adelantado a tomar su partido, y que VS hubiese podido llegar a tiempo de l'emporterw(36).

A los pocos dias, Aranda volvía a la carga y remachaba el clavo con la siguiente carta: "Señor don Iñigo invicto, Avrá crehido VS ganarme la mano escribiendo al Sr. Papá de la Novia [el duque de Hijar], que VS estaria por ella en quantas disputas tuviésemos. Pues sepa VS que ya les tenía yo 
anticipada esta noticia. Assí respondo a parte de la de VS del 16 del pasado; y en cuanto a la curiosidad que le quedaba a VS, creyendo que no podría responderle yo por ahora, le diré de prevención que las herramientas mías están [como] de 25 años. ¿Me explico?. Secundum Berwick.

Ayer estuve de visita en casa de la viuda de Rojas, y hallé en ella al Novio, [el conde de] Asalto; hablamos de que yo avía dado el Tocsin a los viudos, pues también se acaba de publicar la boda de don Victorio de $\mathrm{Na}$ via(37); y hay apariencias de la de Lacy(38) con una sobrina suya, hija de Villaverde. Dije a la señora viuda [de Rojas], que era una cruel en no haver aguardado al regreso aqui de VS, cuya robustez le hubiera tentado quizás. Reimos bravamente, y VS hizo la costa, contento yo como unas Pascuas de zurrarlo de importancia, y de repetir (que VS está) fort comm'un Turc, para que corra la voz, y halle VS facilmente nobia golosa, de modo que, con esse crédito, y la cucaña de las horas del Consejo [de Guerra], para citas extraordinarias, se presente alguna sin dilación a hacer los honores de la casa de VS, y proveer a su castidad. Basta de disparates, quedando siempre de VS, Arandas(39).

\section{RASGOS PSICOLOGICOS DE HEREDIA.}

Los testimonios psicológicos de que disponemos actualmente sólo nos permiten trazar un perfil asaz ténue de Heredia, personaje que pasa por la escena histórica de una manera fugaz e-intencionadamente-borrosa; su decidido empeño en difuminarse fue sin duda la razón principal-no la única-de que se negara a posar ante un pintor. Al faltarnos un buen retrato suyo, ignoramos cómo eran sus rasgos faciales-el brillo de sus ojos, la forma de su nariz y de sus labios, la curvatura de su mentón-y la contextura externa de su organismo.

Esto no obstante, podemos inducir sin excesiva temeridad, que Heredia aparecia al exterior como un hombre pulcro y atildado, de maneras apacibles, silencioso más que parlanchín, y no muy facilmente excitable. Su sentido de la discriminación, su capacidad analítica y su pensamiento claro, habían hecho de él un crítico nada lerdo. Su caligrafía era elegante y meticulosa, y sus escritos, limpios como una pastilla de jabón, producen a 
la vista del lector una impresión sumamente agradable. De naturaleza retraida, sin llegar a tímido, no imponía a nadie su personalidad, ni se sentia llamado a ser empresario de la dicha ajena, lo que no quita para que estuviera siempre dispuesto a prestar ayuda a otros, y a ofrecer su colaboración.

Heredia era muy morigerado en sus gastos, y ello no por espiritu de cicatería, o porque fuera mezquino, sino por la seguridad que da el dinero para tener cubierta la vejez y no depender demasiado de nadie. Buena prueba de ello es el dinero que invirtió en libros, los cuales, además de enriquecer el campo de sus conocimientos, podian prestar una excelente compañía a su vejez de solterón solitario. Amaba el aislamiento, y le gustaba estar solo, pero no con el radicalismo de un cartujo, sino rodeado de gentes que se movieran a una distancia discreta. La patulea acoquinaba su naturaleza reposada, y el tumulto desequilibraba su trabajo no menos que su descanso. En una palabra, aborrecía el ruido y la bullanga indiscriminada, como temía y evitaba la multitud, pero necesitaba sentirse protegido, y notar la presencia recatada de unos pasos cercanos. Cazurro y gruñon, con un fondo insobornable de cordialidad, su humor ácido podía ser a veces hilarante. Todo esto hacía que no se matara por ocultar que su carácter no era muy sociable.

Añádase a esto que la vida cotidiana de Heredia estaba tejida de pequeños hábitos; los defendía con toda la energía de que era capaz, porque salirse de ellos perturbaba su estabilidad; el simple cambio de horarios alteraba su tranquilidad somática. De ahía que la autodisciplina, adquirida a fuerza de actos elícitos, formaba parte de su naturaleza; y si se mostraba exacto en el cumplimiento de sus deberes, con la misma minuciosidad vigilaba su régimen alimenticio, sus horas de sueño y de trabajo, y los altibajos de su salud, porque era tan aprensivo ante las enfermedades-reales o imaginarias-, como respetuoso con sus digestiones(40).

A juzgar por estas manifestaciones externas, un observador superficial hubiera podido tachar. a Heredia de egoista-o al menos de egocéntrico-, siendo así que, cuando era menester, añadia horas extraordinarias a su jornada habitual de trabajo. La etiqueta de "egocéntrico", que le colgaba a veces Aranda, no se debia a que fuera un sujeto perezoso, indolente o remolón, sino tal vez a la capacidad que tenía para decir "no", 
y para decirlo en serio y sin titubeos. Hombre práctico y con los pies sobre la tierra, sabia plantarse inapelablemente cuando preveia que las cosas podian Ilevarle demasiado lejos.

Decíamos hace poco que Heredia era parco en sus dispendios. Algo parecido le ocurría con la movilización y el desembolso de sus sentimientos. Como cualquier hijo de vecino, llevaba puestas sus necesidades emocionales, pero las ocultaba, frenando los galopes insensatos-y los trotecillos retozones-de su corazón, porque sentía una especie de alegría a despilfarrar sus emociones de una forma torrencial. ¡Nada de fantasias desatadas!. No cabe duda de que Heredia tenía sus ilusiones; lo que sucede es que no se las hacia facilmente. La vida, con sus roces y cicatrices, le habia convertido en un verdadero individualista, $y$, a fuer de tal, defendía sus fronteras sentimentales, sin transgredir las ajenas. Bien capacitado-o al menos más idóneo que otros muchos-para llevar con serenidad una vida de célibe, aceptaba con naturalidad su propio destino sin rebelarse contra él, y tampoco sentia excesivos deseos de ser padre, porque su personalidad no necesitaba de hijos para "realizarse emocionalmente", como dicen ahora los entendidos en estas materias.

Con igual seguridad podemos afirmar que Heredia no habia nacido para ocupar un puesto de ejecutivo, o dirigir una gran empresa, porque no era un trepador ambicioso o un arribista agresivo, ni necesitaba ver su nombre, sobre la puerta, en letras de oro, para sentirse satisfecho de sí mismo. Esto no significaba que fuera un rutinario inerte. Esperaba y desaba los cambios y las mejoras, pero dejaba que otros practicaran la violencia, y ello no por cobardía física o moral, sino simplemente porque no estaba hecho para los fragores de la lucha. Lo suyo era realizar las ideas de otros, moverse entre las rodajas ocultas del mecanismo para hacerio funcionar, y rematar las tareas sin trompetas ni fuegos de artificio, procurando que otro ocupara el primer plano o la portada de una revista publicitaria. Como prefería ser que figurar, hubiera sido muy difícil, sino imposible, encontrarlo enarbolando una pancarta, o desfilando con bombo y platillos al frente de una manifestación. Para él lo sagrado no eran los títulos pomposos, ni los puestos encumbrados, sino la seguridad que le producía ocupar con dignidad el que le había tocado en suerte, porque sabía experimentalmente que es el hombre quien hace el cargo, y no el cargo al hombre. 
Su organismo no toleraba la tensión de tener que dar órdenes, o de ser reponsable de las acciones de otros. En resumidas cuentas, Heredia no valía para mandar, pero como hombre de confianza no tenía precio. No es, pues, extraño que Aranda, conocedor de su estabilidad, y del valor que tenía su lealtad en el mercado de los servicios, lo cuidara como una joya, y lo fuera ascendiendo hasta convertirlo en su mano derecha. Pero el conde procedió paulatinamente y con mucho tino, como si sospechara que Heredia no estaba preparado para los ascensos bruscos, y que un avance demasiado rápido en el escalafón le hubiera asustado en lugar de halagarlo.

Cuando Aranda se fue a España en diciembre de 1783, y se detuvo varios meses en Madrid, sabia perfectamente que podía dejar, con toda seguridad, el cuidado de la embajada en manos del avezado Heredia, y no ya porque le correspondiera, como secretario de la legación, sustituir al embajador durante su ausencia, sino porque el sentido de ética y de repsonsabilidad del graense eran tan absolutos, que no necesitaba de la supervisión de su jefe para llevar puntualmente y sin agobios el peso de la representación.

Heredia correspondio, por su parte, con la moneda más noble a todos estos detalles - en ocasiones paternales-de su paisano Aranda, lo que no era óbice para que en ocasiones se erizara momentáneamente, poniéndose hosco e irritable. El conde se reía de tales reacciones, tomándolas a broma, e incluso provocándolas de intento, porque sabía que su secretario era tan rápido para soltar un bufido inofensivo, o poner mala cara a una broma sobre sus pequeñas manías, como para prestar su ayuda sin necesidad de pedírsela. Heredia aceptó con gratitud y sin reticencias de ningún género su situación de "hechura" de Aranda, y nunca lo traiciono, ni le volvió jamás la espalda, como hicieron otras "criaturas" del conde.

Se dio traza para manifestar su fidelidad de una forma tranquila y poco ostentosa, pero constante, sin presumir de su confianza con Aranda, ni valerse del nombre y la autoridad de éste para beneficiarse. Colaboró eficazmente en la empresa de apoyar y dar brillo a la carrera política de su señor, en lugar de buscar su medro personal, o la expansión de su propio "yo". Como el éxito no se le subía a la cabeza, y su modestia continuó sien. do la misma que al comenzar su carrera en la covachuela de Gracia y Justicia, consiguió que Aranda no quisiera separarse de él. Finalmente, el 
hecho de que fuera servicial sin caer en el servilismo, hizo que el conde nunca lo manipulara, y que Heredia no se viera precisado a echar mano de argucias y regiros hipócritas para tratar a su jefe y convi:yir con él.

\section{EL FUNCIONARIO HEREDIA Y SU VETA DE "ILUSTRADO»}

Pero volvamos al año 1756. No parece que Heredia estuviera satisfecho de la vida que llevaba en Huesca, hospedado en San Vicente (colegio de escasas rentas), y hasta hay indicios para creer que el ambiente de la Universidad Sertoriana se le antojaba una "cátedra de Pilatos»(41). Por eso, acogiéndose a la costumbre fomentada por el citado marqués del Campo de Villar, y por otros "facedores" de becas colegialas, según la cual los estudiantes que hubieran hecho su carrera universitaria en calidad de colegiales tuvieran preferencia, o fueran preferidos a los "manteistas", para ocupar los cargos eclesiásticos, los puestos de administración, y las oficinas ministeriales (los colegiales menos aventajados eran destinados al Consejo de Inquisicion, por aquello del praestet fides supplementum)(42), Heredia se decidió a cortar con el pasado, y en mayo de 1757 lo encontramos, según dijimos, trabajando en la covachuela de la Secretaría de Gracia y Justicia(43).

Por un real decreto del 30 de noviembre de 1714, Felipe $V$ habia creado las Secretarias del Despacho, o lo que hoy llamamos Ministerios. A partir de esa fecha, los oficiales de dichas Secretarías-llamados vulgarmente "Covachuelistas"-dejaron su condición de unidades fijas, y formaron las filas de los funcionarios ministeriales, con opción a subir en el escalafón, desde oficial, o simple minutante, hasta embajador o ministro de Estado.

Según Canga Argüelles, "el covachuelista era un hombre público, que se iniciaba en la práctica de la difícil ciencia de Estado, y en la recta aplicación de sus máximas a los casos que ocurrieran en el Ministerio en que trabajaba. Por lo mismo, debía conocer los verdaderos intereses, las leyes y las costumbres de la nación, cuyo servicio había tomado a su cargow(44). Un Secretario del Despacho, con poco talento, podia ir muy lejos si disponia de un buen plantel de "covachuelistas", y no hacía nada, aunque fuera un genio, si en sus oficinas no encontraba más que holganza, rutina 
en el despacho, e ignorancia en la redacción de las minutas. Las Secretarias del Despacho caminaban entonces por la senda rutinaria de la costumbre, pues no tenían ningún reglamento que las rigiera; solo durante el reinado de Carlos III (1759-88), y más tarde con Godoy, cobrarian una consistencia organizada(45), comenzando a hacer realidad aquel diálogo que $\mathrm{M}$. Baring pone en boca de dos ciudadanos ingleses:

"-¿Mr. Chipps es liberal o consevador?-preguntaba uno de ellos.

-Era liberal y ahora es liberal unionista; en otras palabras, conservador-repuso el otro.

- ¿Piensa Ud. entonces que no hay diferencia?.

-No la hay ninguna entre liberales, conservadores, radicales o democratas; todo me parece un juego, y bien tonto por cierto.

-Pero gobiernan el pais.

-No. Pronuncian discursos y engañan al pueblo. Es todo cuanto saben hacer. Al país lo gobiernan los funcionarios permanentes, y no del todo mal. Lo demás es una farsasx(46).

Poco a poco, los "covachuelistas" de las secretarías ministeriales fueron formando un cuerpo propio, y, tal vez como defensa; se creó "un espíritu golillesco", que Pizarro calificaba de fatal. Un "covachuelista" cualificado, como era José Agustín de Llano, futuro embajador de España en Viena, escribiendo a su colega de covacha J. N. de Azara, le decia: "Tenga Vm, presente que, si los frailes y los clérigos nos aborrecen, los Militares nos desprecian, y al margen de esto quieren aprovecharse de lo que los demás sabemos, y ellos, por holgazanes, no han querido aprender. No hablo de todos todos [sic] en una y otra clase, sino de la generalidad

Esto no significa, sin embargo, que los "covachuelistas" se unieran siempre para defenderse; por el contrario, tenian sus piques y sus desquites, $y$, como confidentes de sus respectivos jefes ministeriales, participaban en las rencillas que éstos solían tener, a su vez, entre sí. Aun así, constituían un poderoso grupo de presión y de influjo, por la confianza que gozaban en general de sus superiores, a los que aconsejaban-animándoles o disuadiéndoles-disimuladamente, y por la eficacia de tales equipos, ya que si sus miembros querian, se despachaban los asuntos ministeriales, y de lo contrario se estancaban. De ahí la advertencia dirigida a los ministros con la siguiente aleluya: 
"Procure cada cual con mil cautelas,

Tener ganadas a las covachuelas'(48).

Heredia comenzó, pues, a trabajar como minutante en la Secretaria de Gracia y Justicia, y en la atmósfera de su covacha fue llenando día tras día, con letra nítida y perfilada, montones de oficios, cartas, minutas y memoriales, en una labor callada, impersonal y aparentemente incolora, pero imprescindible para la buena marcha de la administración y de la politica del Gobierno.

Pero Heredia, además de "covachuelista" o minutante, era alguna cosa más, porque difícil es-como apunta Ortega-que un hombre, junto a su profesión, e incluso junto a su vocación, no tenga algunas aficiones. Resulta gratificante fijarse en ellas, porque suelen integrar el yo de la personalidad humana. En sus ratos extraministeriales, Heredia se dedicaba, entre otras cosas, a la lectura, pues no era hombre que le gustara frecuen. tar los estrados, ni le tentaba el cortejar a las damas. La afición a los libros se convirtió para él en una necesidad. Prueba de ello es la librería o biblioteca particular que se iría formando poco a poco, durante su estancia en París, y de la que hablaremos más tarde. De momento, la lectura de ciertos libros, unida a la atmósfera que se respiraba en las covachuelas ministeriales, iba dejando en Heredia un poso "ilustrado", exacerbado por el ambiente inmovilista de algunos sectores de la sociedad española.

Cada vez era relativamente mayor el número de personas que percibian cómo ciertos ambientes dominantes de la nación seguían empeñados - más bien por rutina_en mantener un clima de inflación religiosa(49). Ello se debia en parte a que en la España de entonces no bastaba con ser un católico creyente; en cierta manera, habia que ser también crédulo para poder pasar por un español "castizo". Una creencia piadosa se tomaba por un dogma, una opinión de escuela se transformaba en un axioma teológico inconcuso, y de una tradición más o menos legendaria se hacía un artículo de fe.

Don Manuel de Roda, que en 1765 sucedió al marqués del Campo de Villar en la Secretaría de Gracia y Justicia, escribiendo a su corresponsal J. N. de Azara, destinado a Roma como agente de preces, le decía a este respecto: "Muchas gracias por el tomo primero de la Historia Eclesiástica, del P. Saccarelli, filipense. Nos quita la venida de Santiago a España, y por 
consiguiente la de $\mathrm{N}^{\mathrm{a}}{ }^{\mathrm{a}}$ Señora [del Pilar] a Zaragoza, pero no me asusto por estas cosas, aunque soy Zaragozano. Sólo por este capitulo, disgustará aquí esta obra, y si Vm. remite aquí, como intenta, los cincuenta ejemplares para prueba, pueda que se afilen las plumas de los apasionados a estas tradiciones para impugnarle [...]. En Roma todas las controversias de jurisdicción y de autoridad se hacen guerra de Religión, y en España se descuidan estos asuntos, y antes bien tomamos el partido romano; pero en lo de fábulas piadosas y tradiciones devotas, se disputa "tamquam pro aris et focis", se empeña el Santo Oficio, y se trata de impíos y de herejes a los que las niegan o disputan. Quien haya de escribir aquí en España con critica, es preciso que tenga vocación de mártir»(50).

"La piedad auténtica es útil para todo», pero cuando el espiritu masivo y rutinario hace de ella una muestra de ostentación y de vanidad social; cuando se aceptaban sistamáticamente muchas patrañas, y se llamaba hereje a un Feijóo, porque no suscribia ese espiritu(51), entonces se explica mejor esa especie de sorda irritación de muchos hombres cultos, como Heredia, cuyo espiritu crítico se iba agudizando al contemplar ciertas tradiciones míticas que pasaban por lo más genuino de la Religion(52).

Entre las actividades extraministeriales de Heredia, a las que he aludido hace poco, hay un aspecto curioso que deseo señalar. Como otros coetáneos suyos, también él leia tomando notas, o haciendo extractos, que transcribia en una especie de cartapacios o «silvae rerum». Pues bien, es interesante consignar que Heredia dedicó uno de estos cuadernos a anotar en él, cronológicamente, cuantos casos de frailes intrigantes, monjas visionarias, clérigos trabucaires, o prelados escandalosos llegaban a su noticia, de suerte que aquellas páginas constituyen una antología de lamentables defecciones.

Por ceñirnos a unos pocos casos, en esta poliantea, encontramos un relato de rebordes eróticos, sobre los capellanes de sor Magdalena de la Cruz, famosa monja andaluza, que tenía estigmas en las manos, y estaba poseida-a su juicio-por dos demonios llamados Balbán y Pitonio(53). También se da cabida a un "Relato de los hechos y cosas más notables que sucedieron al Rdo. P. Maestro Fray Pedro Matilla, confesor del rey Carlos II, el Hechizadon; y se recogen las peripecias del militar portugués Manuel Freyre da Silva, que se hizo carmelita descalzo con el nombre de 
Fray José de San José, y desde. 1735 comenzó a publicar clandestinamente "El Duende Político", hojita semanal, cuyas famosas "verdades y mentiras", especie de letrillas a la manera de Góngora, ponian en solfa al ministro Patiño, hasta que el autor fue descubierto, produciéndose en la Corte el consiguiente escándala(54). Haciéndose eco de los vientos regalistas y anti-jesuíticos, que soplaban cada vez con más fuerza por las esferas ministeriales de Madrid(55), Heredia transcribia un epitafio satírico, en elegante latín, contra el inflexible cardenal inmunista Luis Torrigiani; y en la página siguiente reproducia un discurso antifrástico, lleno de sandeces, en el que el P. Ricci, general de los jesuitas, abogaba por los regalistas, y pedía instantemente la extinción de la Compañia de Jesús.

Qué pretendia Heredia con esta extraña "crestomania"?. ¿Justificarse ante sí mismo con el argumento de que, para ser como alguno de estos sujetos, valia más no haberse hecho sacerdote?. Heredia era mucho más inteligente y morigerado que todo eso, pero sea de ello lo que fuere, no resulta descabellado inducir de otros casos análogos, que lo que tal vez intentaba con este "divertimento", era manifestar, más o menos inconscientemente, un sentimiento bastante arraigado entre no pocos cilustrados" españoles: su velado menosprecio por la casta clerical, colectivo que tenia poco que ver con la auténtica Religión(56).

Como ya insinué más arriba, Heredia era políticamente monárquico, con un concepto teocrático de la realeza, lo cual no significa necesariamente que fuera partidario de la dinastia borbónica entonces reinante, antes muy al contrario. Su padre habia pertenecido, con hacienda y vida, al bando del archiduque Carlos, y el vencedor Felipe $V$ no sólo había castigado a los reacios a su causa (motivo por el que los Heredia de Graus habian pasado una época de persecución y de apreturas económicas), sino que, con el Decreto de Nueva Planta, desmochó para siempre los derechos forales del Reino de Aragón. Este golpe-otros lo Ilaman «atentadon-mantenía vivo el sentimiento nacionalista(57) de no pocos aragoneses avecindados, o no, en Madrid.

Por eso, no deja de ser significativo el constatar que la «librería" de Heredia no contiene ningún tipo de obras-digamos- "proborbónicas", que defiendan de alguna manera la legitimidad de la dinastía reinante entonces en España, al paso que encontramos un folleto semiclandestino 
- Le partage du lion(58) - desde cuyas páginas se atacaban las pretensiones leoninas del ambicioso Luis XIV, empeñado en que los Borbones sucedieran a Carlos II el Hechizado (1665-1700) en el trono de la monarquía española(59).

A la vista de estos indicios, tampoco sería muy descabellado el insinuar, que una de las razones por las que el conde de Aranda, cabeza del "partido aragonés»(60), tomó a Heredia como secretario suyo, fue por esta afinidad de ideas políticas, de suerte que se lo llevó consigo a Valencia, como ya dijimos, y lo mantuvo a su lado durante más de cinco lustros.

Heredia volvió de Valencia a Madrid a primeros de abril de 1766, acompañando a su señor, el conde de Aranda, al que Carlos III acababa de nombrar presidente del Consejo de Castilla y capitán general del Reino de Castilla la Nueva. Al saber esta noticia, el erudito G. Mayans escribía a la condesa Aranda desde Oliva: "Señora: En grandes regocijos, pocas palabras. Yo estoy casi como mudo, y mi gozo no sabe explicarse. Solo dice: "Viva el Exmo. Sr. Conde de Aranda; sea feliz España, y séalo por su medio". Tenga V.E. este gozo, y sea supremo. Dios continue en sernos propicion(61).

Aranda, que deseaba tener a Heredia junto a sí, lo hizo secretario de la Capitania General, y de la presidencia del Consejo de Castilla. No contento con esto, consiguió que nombraran a su paisano Comisario de Guerra. Heredia desempeño estos cargos hasta junio de 1773, fecha en que seria destinado a París(62).

Según Aranda, "Siétamo y Graus» habian logrado, para diciembre de 1766, restablecer la paz interior de España, gravemente alterada por la nube de motines y algaradas que estallarían a la sazón en la Península. Sabemos lo mucho que trabajó Aranda en esta empresa tan compleja y espinosa(63), y el mismo conde reconoce lo útil que le fue, en este empeño, la colaboración callada, pero eficaz, de su secretario. Es éste-como ya dijimos-un rasgo muy acusado de Heredia, hombre de penumbra, cuya personalidad tendía a pasar inadvertido, y a ocupar los prudentes segundos planos, fiel a la consigna horaciana, según la cual, "en los choques de trenes nunca mueren las hormigas $(64)$.

El escritor José Cadalso (1741-82), que trató de cerca a Aranda, traza en sus Memorias un esbozo sugestivo del ambiente que reinaba, durante aquella época, en la "posada" del presidente del Consejo de Castilla; nos 
habla del caballo que vendió al conde, y de los turbios manejos de sus favoritos-Joaquín Oquendo y Antonio Cornel-que engañaban a su señor(65), pero en todo su relato no menciona para nada el nombre de Heredia, y eso que el Graense vivía alojado en el mismo palacio que su jefe Aranda, y Cadalso tuvo que encontrárselo muchas veces por los pasillos, o en las tertulias y representaciones teatrales organizadas en su morada por el aristócrata aragonés.

A pesar de estas sombras, dos rasgos apuntan en el perfil borroso del Heredia de estos años de Madrid; dos rasgos que lo definen-ex ungue leonem-como un católico "ilustrado", en la acepción "crítica" del vocablo(6), y nos dan a conocer: su regalismo temperado, y su docilidad frente a la censura inquisitorial de los libros.

Los «ilustrados" españoles de mediados del XVIII abominaron del deismo, y se mantuvieron fieles al catolicismo tradicional de la nación, aunque lo querían expurgado de algunos elementos excesivamente politizados de su contextura. Digo de "algunos", y no de todos, porque para ello, muchos "ilustrados" españoles hubieran tenido que liberarse, a su vez, de la ganga de elementos "religiosos" adheridos, como rémoras, a su ideología regalista(67). $Y$ esa liberación les resultaba tan árdua, como la dificultad que encontraba, por su lado, la jerarquia eclesiástica española para cortar sus inveterados compromisos "políticos" con dicho regalismo, y romper el sistema de sus relaciones con un régimen absolutista con el que habia pactado, y bajo cuya protección se encontraba muy agusto.

En la práctica, la jerarquía eclesiástica española, dependiente de la Corte de Roma, propendia a mantener la confusión de poderes: el civil y el eclesiástico, actuando ora con uno, ora con el otro, y si lo creía necesario, con los dos. Por el contrario, los regalistas propugnaban la división de tales poderes, distinguiendo el temporal o civil, del espiritual o eclesiástico, pero se injerian ocasionalmente en el terreno de las cosas que eran espirituales por naturaleza o por accidente. Lo triste es que, en tales debates, cada bando exigia al otro la división de poderes, pero en la práctica tendian a confundirios, y actuaban indiscriminadamente con uno y con otro68).

Pues bien, refiriéndose a estos tiquismiquis jurisdiccionales, escribía Heredia en 1769 al agente J. N. de Azara, compañero suyo en San Vicente de Huesca, y le decia: "Veo que el Gran Duque [de Toscana] no se anda en consideraciones con los reos refugiados en los asilos(69), y soy del parecer que quien comete un crimen debe ser llevado a prisión. No comprendo el 
interés que puedan tener los pretes de ahí en estos asuntos, pero sucede lo propio con los de aqui, que predican la humildad a los projimos, y ellos no buscan más que dominio.

«Recuerdo haber leído, en mis años de Huesca, un pasaje de San Hilario, muy en consonancia con casos como este; me agradó tanto que lo transcribí entonces, para conservarlo, y te incluyo su copia. Dice así aquel santo Obispo, sobre que debe darse al César lo que es de éste, y a Dios lo que es de Dios: Con esta respuesta, Cristo estableció un término tan justo, entre el menosprecio de lo temporal y la ofensa al César, que liberó de todos los cuidados y obligaciones seculares a los que viven entregados al servicio de Dios, al ordenar que debía darse al César lo que a éste pertenecia. Pues si nada de lo suyo retenemos, no estaremos obligados a devolverle cosa alguna. Por el contrario, si nos injerimos en lo que él entiende; si usamos de su derecho de jurisdicción, y si, cual otros mercenarios, procuramos sacar provecho de su patrimonio, entonces no se nos hace ninguna injusticia si se nos exige que debemos devolver al César lo que es del César, y dar a Dios las cosas que le pertenecen: el cuerpo, el alma y la voluntads(70).

Como católicos, los «ilustrados» españoles pretendian defender el derecho a seguir siéndolo, sin tener que suscribir, para ello, no pocas opiniones teológicas, filosóficas, e incluso estéticas, que el catolicismo tradicional, historificado, habia ido injertando en su tronco, hasta el punto de cubrir con una frondosa hojarasca algunos puntos esenciales del núcleo principal de las creencias. Esto significa, con otras palabras, que los «ilustrados» españoles del XVIII estaban muy lejos de saltar por encima de los dogmas, o de hacer de la moral católica menos caso del que hacían ciertos rigoristas "ortodoxos", acostumbrados a expender recetas teológico-morales... para los demás. Les parecia muy bien que la jerarquía eclesiástica y el clero español trataran de proteger, por encima de todo, "la fe del pueblo sencillo" (los mismos «ilustrados» practivaban esta demofilia paternalista, y convenían con Fontenelle en que el pueblo sencillo no debía conocer ciertas ideas), pero con la misma convicción pedían, si no la protección, al menos el respeto de esa misma jerarquía para con la fe de las minorías «ilustradas». 
Como ya anoté en otro lugar, y no hay por qué repetir71), muchos de aquellos «ilustrados" españoles podrian tener-y de hecho tenian-una mentalidad regalista, abierta al mismo tiempo a las nuevas ideas científicas que corrían por Europa; pero cuando se trataba de lecturas, todos ellos hilaban muy fino, y pedian el correspondiente permiso a la autoridad eclesiástica para poder tener y leer libros prohibidos, o incluídos en los Espurgatorios.

Ignacio de Heredia no podía ser una excepción, y obtuvo esta licencia nada menos que por partida doble. La primera vez el 21 de octubre de 1766, de manos del inquisidor general, don Manuel Quintano Bonifaz, que le concedió la facultad de leer y retener, con la debida cautela, libros prohibidos, a excepción de los de Maquiavelo, y aquellos otros que «trataran exprofeso de materias contra nuestra Sagrada Religión, y de obscenidades s;72). La segunda fue en 1779, encontrándose ya en París, y esta vez no se anduvo en chiquitas, sino que recurrió al mismo Sumo Pontífice, por medio de su amigo el agente Azara, con el fin de impetrar la referida licencia «per maggiore sua erudizione". El 18 de setiembre, Pío VI le concedió vitaliciamente el permiso solicitado, aunque se excluían de él los libros que utrataran exclusivamente de Astrologia, de Cuestiones Judiciales, y de cosas obscenas $\times(73)$.

\section{HEREDIA EN PARIS}

No es de este lugar exponer las causas por las que el conde de Aranda fue enviado, como embajador de España, al «dorado ostracismo» de Paris. Aquí nos interesa más señalar que el nombramiento oficial del conde para dicho cargo está fechado el 13 de junio de 177374); y que el 26 del mismo mes, el ministro de Estado, marqués de Grimaldi, escribio a Heredia una carta de oficio comunicándole que, en vista del buen celo desempeñado desde 1776 el cargo de secretario del Consejo de Castilla, a las ordenes del conde de Aranda, «S. M. el Rey-le decía textualmente-ha venido en nombrar a VS oficial de esta primera Secretaria de Estado. Como S. M. tiene resuelto-añadia-que el secretario de la Embajada de España en París sea siempre uno de los oficiales de la referida Secretaría, ha eiegido a VS, que relevara a don Fernando Magallón(75), con el sueldo anual de 600 doblones sencillos desde la llegada a aquella Corte, y la ayuda de costa de 500 doblones de oro, por una vez, para [cubrir] los gastos de viaje y establecimientow76). 
El 14 de agosto de 1773, Grimaldi remitió a Aranda las Instrucciones que debían servirle de pauta general para el desempeño de su embajada en la Corte de Versalles(77). Después de despedirse del monarca, y del ministro Grimaldi, que hasta septiembre de 1776 seria su jefe ministerial, Aranda partió del sitio real de San lldefonso en compañía de su fiel secretario Heredia(78), que el 28 de diciembre de 1772 habia profesado, como caballero pensionista, en la ilustre Orden de Carlos III79).

Aranda llegó a Paris el 8 de setiembre de 1773, y el 12 tuvo su presentación ante Luis XV. A los dos meses y medio de llegar «al país del buen gusto por las modas", envió a Grimaldi un largo informe en el que resumía sus primeras impresiones. "Todo lo inglés-escribia-se aprecia sobre manera; de los demás países se habla como si fuesen de poco valor, y de España están llenos de las impresiones más bajas y falsas que se puede imaginar, sobre sus usos y costumbres»(80).

No parece, sin embargo, que Aranda y Heredia se sintieran tristes o abrumados en su nuevo destino, antes muy al contrario. Como buenos baturros, supieron hacer de la necesidad virtud, y pronto se dieron traza para sacar jugo a cuantas ventajas y novedades les ofrecía la populosa capital francesa, en la que, dicho sea de paso, nunca se sintieron realmente "desterrados"s.

Es bien sabido que el fiscal José Moñino, futuro conde de Floridablanca, habia llegado a Roma en julio de 1772 con la importante comisión de conseguir del papa Ganganelli la total supresión de la Compañía de Jesús. Para forzar al pontífice a dar este paso lo antes posible, Moñino- respaldado por Madrid y Versalles-ofreció a S. Sd., como gambito, la devolución de Aviñon y del Venesino, territorios pontificios ocupados por Francia a raíz del llamado Monitorio de Parma (1768). El 16 de agosto de 1773, Clemente XIV expidió el breve Dominus ac Redemptor noster, por el que extinguía la Compañia de Jesśus, y la Corte de Versalles, presionada por Carlos III, no tuvo más remedio que cumplir su promesa. El embajador Aranda recibió de su jefe Grimaldi el encargo de ultimar la transacción, y concluir los trámites de la restitución de dichos territorios(81).

Con este motivo, Aranda escribió el 25 de octubre al "golilla» Moñino las siguientes líneas confidenciales: «llustrísimo. No puedo menos de manifestar a VSI que siento de veras su regreso a las trampillas legales, habiendo tenido VSI la dicha de ausentarse de ellas, al salir de España para 
ocupar la embajada de Roma, y habiendo manifestado con su talento que "maiora te vocant". A quien acompaña un prospectus y una labia, como a VSI, ninguna puerta se le cerrará.

"No me reconocería VSI si me viera de golpe, con vestidos, comidas, cenas, cazas a caballo, siguiendo a este soberano, y mudado de vida enteramente. Bien creo que la partida de VSI de esa Corte de Roma pueda diferirse aún, pero no me causaria tampoco novedad el que se abreviase, habiendo de ser D. José Agustín de Llano el sucesor. Sea cuando fuere, puesto que VSI ha de hacer un largo viaje de regreso [a España], téngame por hombre de bien, y véngase por París, aunque no sea sino por un mes, para tomar una tintura de lo que es esto. Sobre que un dia u otro dejará VSI la golilla, y se hará corbata para siempre, bueno es que vea el mundo viviente, y que no se lo cuenten. Yo me mudo a una casa donde tendré un par de alojamientos muy buenos para huéspedes; sea VSI uno de ellos, y verá qué vida tranquila gozaremos aquellos días, y tendrá toda la libertad que apetezca, sin más sujeción que a los cumplidos precisos, y hacer en lo demás su buena voluntad. Mande VSI a su verdadero servidor. Aranda»(82).

Como puede notarse, Aranda se encontraba contentísimo, respirando a pleno pulmón los aires de París, y nadie podría deducir de unos párrafos de invitación tan sinceros y amistosos que, andando el tiempo, el señor aragonés y el togado murciano, convertido en ministro de Estado desde 1777 , terminarían a la greña, tratándose como verduleras. Pero esta es otra historia.

Lo que aquí nos interesa señalar es que Heredia aprovechó el correo que su señor despachaba a Roma, para enviar a su amigo Moñino, más que una carta, una sabrosa charla de café en la que, entre bromas y veras, el graense se retrata de cuerpo entero, $y$, sin miedo a censuras, nos ofrece una instantánea de sí mismo, que no tiene pierde. "Amigo y dueño-le decía-, No quiero perder la ocasión de decir a Vm que he recibido su carta con muchísimo gusto, por el buen humor que Vm gasta en ella; la he leído al Sr. Embajador [Aranda], que la ha celebrado igualmente, y más ha dicho: que siente el pensar que $\mathrm{Vm}$ ha de volver a ponerse la Golilla.

«Vm piensa ofrecerme una gran cosa con poner a mi disposición toda la potestad espiritual de esa Corte romana; pues sepa Vm que para nada de esto la he de menester. Acá, los Embajadores y adherente no oyen Misa, 
y sí asisten a la que el Rey [Luis XV] oye, leen la Gazeta o están de conversación durante ella, y comen carne todo el año. Al que no le basta una Metresa acreditada, y reconocida por tal, tiene dos o tres, hasta donde llegan sus fuerzas de cuerpo y bolsillo. ¿Quién puede dudar que, cuando esta práctica es constante y general, estará fundada en buenas razones? ¡Véngaseme ahora Vm, a vista de esto, a hacer ostentación de sus facultades romanas!. Reconozca Vm nuestra superioridad, y entonces me resolveré a pedir a la Asamblea de Embajadores, que se tiene todos los domingos en París, que lo admitan a Vm al goce y uso de estos privilegios, y que se le despache el rescripto en debida forma.

"Amigo, si vuelvo a España, como he venido acá, podrá Vm besarme el pié con más fe que al Santo Padre, pero temo mucho que no pueda presentarle sino un zancarrón como el de Mahoma. Manténgase Vm bueno, y mande cuanto guste a su amigo. Heredian(83).

Dejando a un lado el relato de los roces de Aranda con Grimaldi, y con el conde de Floridablanca, sucesor del genovés en la Secretaría de Estado, no creo muy aventurado suponer que el gran señor aragonés habló con Heredia de sus proyectos políticos, y le consultó muchas veces antes de enviar secretamente a Madrid, en abril de 1781, su «Plan de Gobierno para el Príncipe de Asturias»(84), en cuyo cuarto solía reunirse "la cábala de los aragoneses", que intrigaban para desbancar al omnipotente "golilla» Floridablanca, y poner en su lugar al conde de Aranda.

Aranda estaba al tanto de estos movimientos clandestinos, porque vivía con los ojos puestos en Madrid, y él mismo enviaba mensajes secretos, que mantuvieran encendida la conspiración; pero al mismo tiempo era "el embajador de familia", y representaba en París a una España, cuyas relaciones con Francia discurrian desde 1761 por los cauces del Ilamado Pacto de Familia(85).

Independientemente de que Aranda sintiera tan poca simpatía por Inglaterra como por.Francia(86), lo cierto es que tal Pacto de Familia-Duclos lo calificaba de folies d'Espagne-tuvo siempre mucho de anémico y de artificial. A pesar de todo, debe reconocerse que, desde un punto de vista puramente historiográfico, el acuerdo franco-español tiene, para nosotros, un valor de esquema indicativo, ya que sus vicisitudes son tal vez la vía más segura para poder captar el sesgo de las relaciones hispano- 
inglesas durante el siglo XVIII; relaciones que no pueden entenderse, a su vez, de una forma adecuada, sin el contrapunto de la presencia de Francia en la escena política.

Hubo momentos críticos en que dicho tratado se convirtió en un pesado compromiso para España, y sus exigencias y malentendidos, no menos que sus intencionadas tergiversaciones, hicieron cada vez más espeso el clima de mutuo recleo(87). Uno de esos momentos se dio con ocasión de la guerra que declararon a Inglaterra las Trece Colonias Americanas, para conseguir su independencia y convertirse en los actuales Estados Unidos de América del Norte.

Francia pactó con las Colonias Americanas sin contar con España, como estaba estipulado en el Pacto de Familia, y nuestro pais se vio obligado a firmar la Convención de Aranjuez (12 de abril de 1779), haciéndose beligerante(85). Según las cláusulas de este convenio, Francia prometía a España tentadoras compensaciones (las grandes mentiras suelen ir precedidad de grandes promesas), pero de todo ello, lo único que hubo de cierto es que España se encontró fatalmente metida en una guerra que, a la postre, sería ruinosa para ella, y por supuesto nada gratificante.

\section{MISION DE HEREDIA EN LONDRES}

Sin entrar en los avatares de esta larga contienda, que ahora no hacen al caso, baste decir para nuestro intento, que Inglaterra reconoció la independencia de las Trece Colonias el 30 de noviembre de 1782. Con alguna anterioridad, las cancillerias de los países beligerantes se habian puesto en acción, al objeto de preparar los preliminares de la paz(89). Según los políticos franceses, las negociaciones se entorpecieron, con riesgo de entrar en vía muerta, a cuasa de las "indecentes exigencias" de España, que el conde de Aranda habia presentado al conde de Vergennes, ministro de Asuntos Exteriore francés, y a Mr. Alleyne Fitzhebert, plenipotenciario inglés llegado a París en agosto de 1782 para tratar este asunto.

Así como Francia había destacado a Londres a Mr. Rayneval, para negociar los preliminares de la paz, y concretar las cláusulas del tratado anglo-francés, parejamente el conde de Aranda envió a Heredia a la capital 
británica(90), al objeto de prepara los preliminares del pacto hispano-inglés. Como puede notarse, las relaciones franco-españolas seguian siendo tan "familiares" que, pese a su estrecha alianza, cada nación preparaba por separado su propio tratado de paz con Inglaterra.

Herdia partió de París el 18 de diciembre de 1782, lleno de vigor y entusiasmo, en compañia de Francisco Angulo, joven pensionado por Carlos III para estudiar la Historia Natural en París, que le serviría de secretario, y llegó a Londres el 22 del mismo mes. Poco antes de embarcarse en Calais, escribía a Aranda: "El 20 a las 7‘45 de la tarde llegué aquí. A las 4‘45 del día siguiente de salir de esa llegaba a Abbveville, sin más descanso que el de veinte minutos en una Posta del camino, para comer un pedazo de salchichón, única comida en 48 horas, con dos tazas de chocolate. Me quedaban trece Postas para ayer, después de tres horas de descanso en Abbeville, envuelto en la capa. Partimos a las ocho de la mañana, y a las diez de la noche llegábamos al arrabal de Calais, donde he pasado la noche. $Y$ entré tan fuerte y vigoroso, que le decía a Angulo que me sentía con valor para ir hasta Constantinopla. Andese V.E. ahora con decir si soy perezoso e idólatra de mis comodidades(91).

Heredia fue muy bien recibido en Londres por el ministro del Foreign Office, lord Shelburne (que calificaba esta guerra de infâme folie), y por lord Grantham, ministro de Estado y afecto a España (donde estaba de embajador cuando estalló el conflicto en 1779), quien el 27 de enero de 1783 lo presentaría al rey Jorge III.

Aunque Heredia vigilaba su régimen gastronómico, no tuvo inconveniente en hacer algunas excursiones por los litorales de la cocina británica(92), y como se le brindó la ocasión de conocer algunos aspectos de la vida londinense, no se privó de asistir a cuantos bailes, convites y saraos le ofrecieron los políticos ingleses. El 24 de enero escribía a Aranda, con un granito de picardía: "Mr. Shelburne ha empezado a atacarme sobre nuestra inclinación por las Bellas, llamándonos a V. E. y a mí Caballeros de Malta, en contraposición a Rayneval y a su acompañante, el vizconde de Vergennes, que tienen [aquí a] sus mujeres, suponiendo que $V$. E. y yo buscamos las de los otros $x^{(93)}$.

Pero estos y otros esparcimientos no desviaron a Heredia de su camino, ni le impidieron actuar con verdadero empeño. Impulsado por su fideli- 
dad a Aranda, se movió con tal eficacia, enviando informes y documentos a París, que el 20 de enero de 1783 los plenipotenciarios Fitzhebert y Aranda pudieron firmar en Versalles, "au Nom de la Très Sainte Trinité», los preliminares del tratado de paz anglo-español(94).

Aunque en Madrid no quedaron del todo satisfechos por este tratado, tampoco les desagradó, pues se dieron cuenta-y así lo reconoció el mismo Floridablanca-, que tal como estaban las cosas en el tapete diplomático, el dúo Aranda-Heredia había sacado en aquella ocasión el mayor partido posible(95). Esto no obstante, la forma fría con que el autoritario Floridablanca acusó recibo del resultado de las negociaciones, deja traslucir su descontento ante el poder independiente de Aranda, que actuó por su cuenta, sin atenerse taxativamente a las instrucciones del ministro de Estado. Por otro lado, tampoco es muy aventurado suponer que Aranda, al interpretar un tanto elásticamente las ordenes de Madrid, hizo como que todo cargaba sobre su propia responsabilidad, o, para usar sus propias palabras, "en lo que las chollas de él y de Heredia les habian dictado»(96), aunque sin traspasar, ciertamente, los límites de unas posiciones que habian sido ya admitidas-a regañadientes - por el Gobierno español.

Floridablanca podría estar más o menos descontento con los preliminares, al margen de la desconfianza que sentia ante cualquier clase de pacto con Inglaterra(97); pero quienes realmente estaban satisfechos de los resultados obtenidos eran Aranda y Heredia, aunque no se les ocultaba el interrogante que este tratado abría en el futuro histórico de las provincias españolas de América del Sur.

El gozo de Heredia era tan grande, que no se atrevía a felicitar por oficio a su jefe Aranda, "de miedo-le decia confidencialmente-de que no piensen que V. E. y yo obramos de acuerdo en todo este negociom(98). En cuanto a Aranda, estaba tan contento de la actuación de su secretario, que llegó a proponer a Floridablanca dejase a Heredia de ministro interino en Londres, y que más tarde podría ir alli de embajador el conde de Fernán Núñez, que estaba al frente de la legación española en Lisboa. Floridablanca desestimó la petición, porque tenía pensado enviar a la capital inglesa a su protegido y confidente Bernardo del Campo, pero, a cambio, Heredia fue nombrado ministro de capa y espada del Consejo de Guerra, por los servicios prestados en el asunto de los preliminares de la paz(99). 
A Heredia, que no suspiraba sino con volver a París, le afectó muy poco el nombramiento de Campo; lo tomó incluso «como si fuera la cosa más indiferente. Acuérdese V. E.-le decía a Aranda-que le manifesté que desearia que sucediese así, y yo no soy capaz de escribir a V. E. otra cosa de lo que piensow(100). Además, Floridablanca le habia hecho saber que si quería podía volver a España, a ocupar su plaza en el Consejo de Guerra, aunque pensaba-y asi se lo prevenía-que era preferible que de momento continuara en París, porque el conde de Aranda deseaba tenerlo junto a sí(101).

Bernardo del Campo llegó a París el 27 de febrero de 1783 en compañía del bilbaino Diego de Gardoqui, futuro embajador de España en los recién creados Estados Unidos. Aranda los recibió en un hotel, cedido por un tal Mr. de Vallet, que hacia provisionalmente las veces de embajada. Campo llevó el encargo de entregar al plenipotenciario Aranda las instrucciones de Floridablanca, para el caso de que se tuvieran en París las negociaciones previas a la firma del tratado definitivo de paz; pero como su presencia era necesaria en Londres (y así se lo confirmó el propio Aranda), se puso enseguida en marcha, a fin de cumplir su misión en la capital británica.

Aranda, escribiendo a Heredia, le decía confidencialmente: «El pobrete Campo, que se desnalgó en Vitoria, llegó aquí con ínfulas de tener facultades in pectore, sobre las cuales exprimirá VS mejor la naranja. Creo que se amansará, pues se va ahi persuadido como [lo estamos] nosotros, pero venia mal informado, para hacerse después un mérito de todo lo bueno que saliese. De momento hemos quedado en que, dados los malentendidos que se ofrecen en algunos artículos referentes al comercio de América, no abrirá la boca hasta estar formalizado el contrato definitivo de paz»(102).

Curado de su resfriado, Campo salió de París con Gardoqui el 16 de marzo de 1783, y llegó a Londres el 21 al mediodía "bueno y alegre como unas castañuelas». Aranda aprovechó la ocasión para poner unas líneas a Heredia, y en su carta le decia: "Hoy, domingo, parte de aquí Campo. Envío con él la presente. Vaya ésta de Siétamo a Graus, y de dos de una misma Universidad (103).

Heredia acompañó a Campo a visitar al ministro Shelburne, y a lord Grantham, que el 24 de marzo lo presentó a Jorge III. Al poco tiempo de 
llegar a Londres, Campo se dio cuenta de que su misión diplomática iba a girar fundamentalmente en torno a los problemas de América del Sur. A su paso por París se lo había prevenido Aranda, quien, ante la situación que iba a crear la independencia de las Trece Colonias, temblaba por el futuro de las provincias españolas de Ultramar, donde había tenido lugar, como prenuncio, la sublevación de Tupac Amaru, saguinariamente sofocada en 1781 por el virrey Jáuregui(104).

El ejemplo de Campo, que se mostraba "muy rumboso y espléndido", animó a Heredia (cuya misión podia darse por concluída con la llegada de aquél a Londres) "a no tratar en adelante el dinero del Rey con la economia y parsimonia con que lo habia hecho hasta entonces", y así, antes de tornar a París decidió hacer un par de viajes por el interior de Gran Bretaña, y visitar algunas ciudades, como Bristol y Portsmouth, con objeto de ver sus instalaciones y factorias, y conocer mejor el país. La tensión creada por los obreros del puerto de Bristol, amotinados contra la situación politica del país(105), obligaron a Heredia a cambiar de itinerario. Concluida su excursión, se despidió de Campo, y el 14 de abril se embarcó en Dover con rumbo al Continente.

Llegado a Calais, donde le esperaban algunas cartas enviadas allí por Aranda (una de ellas era de su hermano el jesuita)(106), Heredia se dirigió hacia el Norte, y se detuvo casi un mes recorriendo los Países Bajos, "aunque mortalmente aburrido y deseando llegar a París, si no fuera-escribía-por la compañia que me hace el tragón de Sanafe", embajador de España en La Haya(107). Finalmente hizo escala en Bruselas, y tomando la carretera de Chantilly se dirigió hacia París, donde entró felizmente el 12 de mayo al atardecer, después de cinco meses de ausencia(108).

\section{DE NUEVO EN PARIS}

Al internarse por las calles de la capital francesa, el carruaje de Heredia no se dirigió al hotel de Mr. Vallet, de donde había partido cuando se fue a Londres, sino a un suntuoso edificio sito en la plaza de Luis XV-actual plaza de la Concordia - a donde se habia mudado Aranda durante su ausencia, y sería su nueva morada hasta el día de su regreso definitivo a España en $1787^{(109)}$. 
El conde de Aranda se había trasladado allí el 12 de abril de 1783- dos dias antes de que Heredia se embarcara en Dover-, y para celebrar la inauguración de la embajada española, el 26 de abril dio «un comidón a todos los danzantes", como llamaba Aranda al grupo de plenipotenciarios, reunidos en París para preparar la firma del tratado definitivo de paz. En una carta confidencial, el conde se permitía tomar el pelo a su secretario, describiéndole el menú, y diciéndole que se alegraba de su ausencia porque, de haber asistido al banquete, era seguro que su afición al buen yantar le hubiera acarreado una buena indigestión(110).

El 3 de setiembre de 1783, el conde de Aranda y el plenipotenciario inglés, duque de Manchester, firmaron el tratado definitivo de la que pasaria a los Manuales de Historia con el nombre de Paz de Versalles(111). La noticia del pacto anglo-español produjo mucha alegría en Madrid. En el oficio que Carlos III envió a Aranda, por medio de Floridablanca, felicitándole por su comportamiento, el propio soberano añadió de su puño y letra las siguientes palabras: "Estoy muy satisfecho de tus servicios, y muy seguro de que me los continuarás s112).

Aranda, escribiendo a su mujer Ana M. ${ }^{a}$ del Pilar, le comunicaba su intención de pedir una licencia temporal para trasladarse a Madrid. Si se la negaban, estaba dispuesto a pedir "seca y redondamente su retiro, pues ya estaba bien haber permanecido diez años sin salir de París». Cuando el conde escribió esta carta a su esposa, todavia no habia habido tiempo material para que Carlos III le felicitara por su actuación en el tratado de paz, pero ciertos rumores llegados a París decían que el monarca estaba muy satísfecho. "Puede estarlo-escribia Aranda-, porque es mucho mejor de lo que yo mismo me prometía en los principios de su negociación»113).

Ese mismo día escribió el conde una líneas muy significativas a su amigo y confidente Tomás Bernad, residente en Madrid. "Señor Senador:- le decia-, ahí va Pomés(114) con todos los Sacramentos de la Paz [de Versalles], y con ello functus fui ofitio [sic] meo totalmente. Queriendo no mezclar nada con esto, dejo pasar unos días para pedir una licencia de pasar ahí a ver mis cosas. Habrá como dos años que me la negaron con motivo de la guerra, y negociaciones que podian ocurrir. Ya pasaron una y otras y ya no hay excusa para negármela. Si me ladan, ahí nos veremos; si no, pediré absolutamente que envien aquí [embajador], y con antverpiae, 
antverpiae, antverpiae(115), que es como se sacan los demonios, me habrán de sacar a mi de aquí; esto para entre nosotros.

"Como ahora ya se publicarán los puntos de la Paz, recoja VS las críticas, y responda siempre si las merecimos, con los desatinos que hemos hecho, y con la inacción de nuestras fuerzas navales desde el principio de la guerra al fin(116). Ya sé que el Señor [Carlos III] está muy contento; con ello y la voz de la nación me contentaré para mi interior»(117).

Esta vez Carlos III-léase Floridablanca - no pudo negar la demanda del conde, quien preparó su viaje para después de la Inmaculada, y partió de Paris dejando la embajada a cargo de Heredia(118). Lo que Aranda no sospechaba, ni remotamente, es que ciertos acontecimientos imprevistos iban a dar muy pronto un cambio notable al rumbo de su vida. Me refiero- como ya dije - al fallecimiento de su primera mujer, acaecido el 24 de diciembre de 1783, y al nuevo matrimonio que el senescente conde contraeria el 14 de abril de 1784 con M. ${ }^{2}$ Pilar Fernández de Hijar, joven de 17 años, de complexión enfermiza y salud debilitada por dos erisipelas, de cuyas secuelas volvería a resentirse en París(119).

Esto no obstante, Aranda la encontraba encantadora, y en todas sus cartas a Heredia, que en punto de mujeres disentía de los gustos de su patrón, no hacía sino ponderársela y alabar sus cualidades, para darle envidia(120), aunque a veces bajaba a tales detalles sobre sus deseos de «entrar cuento antes en el goce de la prebendaw(121), que es mejor pasarlos por alto.

El conde confesaba a Heredia que «andaba todo desorientado con la trápala del nuevo estado en que se embarcaban, pues se veía obligado a atar los muchos cabos que concurrian en una boda de tanto lustre como la suya. En primer lugar, todo lo referente al edificio de la embajada españoIa, situado en la plaza de Luis XV, en el que debían introducirse algunas reformas antes del arribo de "la nueva Embajatriz", empezando por colocar en la galería de abajo "un torno para que la joven Señora pudiera tener des petits soupers de suprise avec sa petite sociétén; y cerrando cuanto antes un agujero del deormitorio del conde, que conducía a una escalerilla por la que se salía a la calle, y por la que las Lolottes de turno tenian, a su vez, fácil acceso a la alcoba de su excelencia el embjador de España(122). 
Aranda llegó a Paris el 20 de mayo de 1784, en compañia de «la joven señora Embajatriz", circunstancia que nunca hubiera sospechado cuando partió hacia España en diciembre del año ànterior. Su amigo J. N. de Azara le felicitaba desde Roma con las siguientes palabras: "Todos escriben y todos dicen millones de bienes de la Señorita, y yo reconozco el buen corsario que ha sabido pillar lo mejor para sí. De otro modo no lo hubiera excusado en mis libros. ¿Qué diablos de temple ha hallado V. E. para sus herramientas, que cuanto más se usan más cortan?. Este secreto debía ser "de comunicantes", para el bien de la humanidad; tanto más que los que estamos en este clima de Italia no podemos contar sino miserias, moho y orín; y las bendiciones del Papa tienen tan poca virtud, que parece que las da siempre en luna menguante [...]. El Cardenal de Bernis, a quien he dejado bueno en Albano, su obispado, esta mañana, me ha encargado con infinita expresión memorias para $V$. E. Dice que siente mucho no conocer al conde de Aranda, y se alegra de que la condesa no lo conozca a él. $Y$ basta de bula romanas(123).

Durante los cinco meses de ausencia del conde, Heredia se hizo cargo de la representación, y ejecutó dignamente los oficios de un encargado de negocios. Uno de ellos consistió en comunicar a Madrid que la Corte francesa habia decidido sacar de alli a su embajador, el conde de Montmorin, para enviar en su iugar al conde de Vauguyon, sujeto al que Aranda calificaba de «hipócrita y de trafiquín embrollador»(124).

Una vez instalado en París, Aranda volvio a ponerse al frente de los negocios diplomáticos, y continuó desplegando en la plaza de Luis XV el mismo boato de siempre. Desde un punto de vista puramente material, la embajada española en París no era solamente un edificio suntuosos, sino una auténtica factoría. En sus dependencias se alojaban el embajador, con sus deudos y familiares, el tesorero real, casado y con familia, un oficial pagador, el secretario Ignacio de Heredia, que gozaba a su vez de lacayo y coche, y un capellán(125). Añádase a ellos el oficial de secretaría, encargado de la correspondencia diplomática, el mayordomo, el caballerizo mayor, el intendente de la casa, los pajes y ayudas de cámara, el «maître d'hotel», el médico de la legación, el delineante de mapas y planos, y la restante servidumbre doméstica, compuesta por los criados, el cocinero, el repostero suizo, que ocupaba una garita junto a la entrad aprincipal, para no hacer 
mención detallada de otros huéspedes estables, o de los invitados circunstanciales que nunca solian faltar.

Al sonar la campana se sentaban cada día a la mesa de la embajada de quince a veinte personas fijas. Aun los dias (más de cien al año) en que Aranda se desplazaba a Versalles como "embajador de familian, se servia la comida, y Heredia era entonces el encargado de hacer los honores a los huéspedes, porque siempre solía haber invitados, "y los viajeros españoles en París tenían acceso abierto a la embajadan. Aparte de este uso cotidiano, había que contar "los banquetes y convites formales". En tales ocasiones, las comidas del mediodía "constaban de treinta a cuarenta cubiertos", y las cenas solían ser "de unas ochenta, cien y más personas, que se reunian a pasar la velada en la embajada española». En resumidas cuentas, que sólo el gasto de la casa-cocina, alumbrado, caldeamiento y caballerizas-arrojaba un saldo anual de cincuenta a sesenta mil librast123).

A estos gastos hay que añadir los salarios de aquellos que Aranda, cual otro mesnadero, llamaba "mis gentes»; asi como "el vestuario y la librea de los sirvientes de la casa; la compra de coches y caballos y su consiguiente entretenimiento; los frecuentes desplazamientos del conde a Versalles, y el mantenimiento de una casa en dicho sitio real, con su alquiler, conserje y silleteros propios»(127). Esta última declaración, salida de la pluma del conde en un informe a Floridablanca, invalida la afirmación, tantas veces repetida por todos los que han copiado, sin crítica, al primero que escribió errónea o intencionadamente: que los monarcas franceses del XVIII adjudicaban en Versalles, por su real cuenta, una casa gratis al embajador de España, a título de "embajador de familia". No había tal cosa.

Otro desembolso nada despreciable lo constituía el gasto ocasionado por el mantenimiento de la secretaría, y la asistencia docente de los escribientes minutantes, "que entre todos hacian de cinco a seis personas"; los porte de los paquetes, el franqueo de las cartas, y en fin, el aposentamiento de los correos y postillones de gabinete, portadores de los despachos oficiales, que solian alojarse en la embajada hasta emprender el viaje de regreso a Madrid; sin contar otros mil gastos personales de representación, de compra de objetos lujosos o necesarios, de fiestas y teatros, y de 
suscripciones a revistas y gacetas, pues ha de saberse que la embajada española estaba abonada al "Mercure de France», al "Journal de Paris", al "Journal Général de France", a la "Gazette d'Amsterdam", al "Courier de l'Europe", al "Journal Encyclopédique de Buillon", a las "Varietés politiques et litteraires", y a otras publicaciones periódicas de menor monta(128).

\section{SERVICIOS OCULTOS DE HEREDIA}

Este era el ambiente confortable que rodeaba a Ignacio de Heredia, y el moverse en un escenario tan bien relacionado y abastado, le brindó una excelente ocasión para ir adquiriendo un cúmulo nada despreciable de conocimientos político-culturales, y contactar con una serie muy variada de personas y personajes que, por distintas razones y motivos, desfilaban por la embajada española de París(129).

Uno de estos visitantes fue el valenciano Antonio José Cavanilies (1745-1804), que en 1777 se había trasladado a la capital francesa para acompañar, como preceptor, a los hijos del duque del Infantado. Cavanilles permaneceria en París hasta octubre de 1789, y durante su larga estancia se dedico, como el ya citado F. Angulo y otros más, al estudio de las Ciencias Naturales, y al conocimiento de la Botánica, campo en el que llegaría a ser un destacado especialista(130).

Pero no es este importante aspecto de la vida del naturalista valenciano el que ahora nos interesa, sino otro asunto fortuito, merced al cual sabemos que Cavanilles se puso en contacto directo con Ignacio de Heredia. Esta circunstancia añade consistencia al hecho de que estos dos españoles, residentes en París, se conocían con anterioridad y mantenian, por otras razones, una buenas relaciones personales. Al fin y al cabo, Heredia era una persona «ilustrada" y un buen patriota, en el sentido más noble y genuino de la palabra. A mayor abundamiento, se correspondía epistolarmente con el erudito valenciano don Gregorio Mayans(131), y como estaba abierto a todas las corrientes del saber, también se interesaba por la Botánica y las Ciencias Naturales, a juzgar por los títulos de algunos libros adquiridos por él en la capital francesa(132). 
EI "asunto fortuiton, al que he aludido, concierne concretamente a la aparición de un artículo, titulado España, que un tal Masson de Morvillers publicó el año 1782 en la Enciclopedia metódica, y en el que este oscuro publicista lanzaba estas injuriosas preguntas: «¿Qué es lo que se debe a España?. Desde hace dos siglos, desde hace cuatro, ¿qué ha hecho ella por Europa". No voy a abordar aquí el "affaier Masson", estudiado por el gran hispanista francés $F$. López con el rigor y la profundidad que son habituales en él, y a que nos tiene acostumbrados(133).

Es fácil comprender la indignación que dicho artículo produjo en no pocos españoles, incluido el conde de Floridablanca; pero dejando a un lado las gestiones diplomáticas realizadas por Aranda ante el conde de Vergennes, para impedir su difusión, lo que aquí nos importa destacar es, que el irritado abate Cavanilles decidió refutar el difamatorio artículo de Masson, y el primer paso que dio con este objeto fue buscar la ayuda de Heredia.

Cavanilles no conocia personalmente a don Gregorio Mayans, pero por recomendación de Heredia recurrió al hermano menor de aquél, don Juan Antonio Mayans, en busca de materiales para redactar sus Observations [...] sur l'article Espagne de la Nouvelle Encyclopédie. El 19 de enero de 1784 escribía Floridablanca a Heredia: "Don Antonio Cavanilles, ayo de los hijos del Duque del Infantado, me ha escrito diciéndome que tiene hechos algunos apuntamientos para refutar el insolente artículo "España", que han puesto en la [sección de] Geografía de la Nueva Enciclopedia, y que VS le ha animado a que lo ejecute. Pide aprobación de su proyecto, y dice que, para perfeccionarle, acaso necesitará algunas noticias de que carece ahi.

"Me han informado que ese sujeto es capaz de hacer una cosa decente, $y$ así puede VS decirle que lleve adelante su intento, que pregunte Ic que no sepa, pues yo haré que se le responda, y que publique su escrito viéndolo antes l'S. Aqui generalmente se mira esa rapsodia [de Masson] como indigna de respuesta, pero es muy propio de un literato español, que reside donde se ha hecho y publicado, darse por entendido y manifestar algunos de los infinitos absurdos que contienem(134).

Cavanilles sometió su escrito a la censura de Heredia, que lo leyó atentamente y dio complacido su visto bueno. El manuscrito fue enviado 
inmediatamente a Floridablanca, quien se mostró tan satisfecho de su contenido, que quiso ayudar a su autor haciendo que la obra se imprimiera a costa de la embajada española en París. Muy poco después, escribiendo Floridablanca a Heredia, le decia: «Devuelvo a VS el papel que ha escrito D. A. J. Cavanilles, impugnando el Articulo Espagne. Haga VS que se publique traducido, costeando la impresión por gastos de la Embajada, y dejándola a disposición de su autor, para que la haga correr distribuyéndola a sus amigos, y vendiéndola a su beneficio; cuidando VS de no manifestarse en nada, a fin de que parezca ser un asunto particular del mismo Cavanilles, que de movimiento propio ha querido defender a su Nación, sin mezcla ni impulso del Ministerio. Cuando se publique, me remitirá VS una docena de ejemplares por los [correos] ordinariosw(135).

El ejemplo de Cavanilles fue imitado, entre otros, por A. Ponz, J. F. Masdeu, F. X. Lampillas, J. Andrés, J. Nuix, el duque de Almodóvar, el abate Denina, M. Rubín de Celis, y J. P. Forner(136), que arremetieron, más o menos directamente, contra Masson de Morvilliers, saliendo en defensa de España. Sus escritos apologéticos se difundieron profusamente, y provocaron nuevas réplicas, que no sólo acrecentaron la fama de sus autores, sino desgraciadamente también la de Masson, quien de otro modo jamás será citado, y carecería de la dudosa fama que hoy tiene.

Todo esto es muy conocido, pues ha sido divulgado por plumas de muy distinto calado; pero lo que tal vez se conoce menos es la ayuda que prestó Heredia a Cavanilles en este asunto, y el papel jugado ocultamente por el graense en torno al «affaire Masson». De ahí la razón de esta breve glosa.

Como ya dejamos dicho, Heredia era un personaje de penumbra; la oscuridad envolvía su dinamismo, y cubría la eficacia de sus actuaciones, porque siempre se mantuvo fiel al propósito-deliberado en él-de pasar inadvertido. Por eso no carece de interés el proyectar un poco de luz sobre estas figuras opacas, cuyo conocimiento resulta a veces revelador, pero siempre es importante, porque "la historia-al decir de J. M. Caso González-no puede escribirse seriamente más que poniendo en relación todos los elementos que participaron en ellax(137).

También se percibe la mano oculta de Heredia en otro asunto muy similar al de Masson, que vino a coronar esta campaña de difamación y de 
menosprecio por "lo español", arteramente montada por algunos plumiferos franceses, con la connivencia-si no con la protección-de las autoridades gubernamentales del país vecino. Me refiero al revuelo producido por la aparición del Viaje de Figaro a España (1784). Su autor, el bre- . tón Jerónimo C. Fleuriot, vertia en este vil panfleto, que tuvo tres ediciones (las dos primeras sin nombre del autor, y la tercera con el pseudónimo de marqués de Langle), cuantos despropósitos y absurdas patrañas pueden decirse en desprestigio de la nación española(138).

"El tal marqués de Langle-informaba Aranda-ha de ser conocido en Madrid, pues estuvo allí en tiempo [de la embajada] del conde de Montmorin, y del caballero Bourgoing, quienes, oigo, tuvieron qué sentir de su mala conducta, y procuraron que se fuese. Parece que entonces tuvo la idea de irse a la Luisiana [...], y no se le proporcionó la ocasión. No fuera malo el prevenirlo al Gobernador de Nueva Orleans, por si, viéndose abandonado de todas las gentes de acá, [se] le pasase por la cabeza la idea de alejarse hacia aquellas partes, pues tal ente en ninguna parte convienew(139).

Hace ya algunos años que el Prof. Ferrer Benimeli puso en claro, con la maestría que le caracteriza, los más intrincados rincones de todo este asunto, cuyos impactos rebasaron el ámbito de la calle, y llegaron hasta las esferas ministeriales(140). Apoyándose en una documentación abrumadora, no se contentó con abrir en canal el libelo del "viajero" francés, sino que al mostrarnos el jaez de sus páginas, dejó vindicada la fama póstuma del conde de Aranda, gravemente injuriado y calumniado en varios lugares del referido panfleto que, durante años, constituiria sin embargo uno de los más socorridos manantiales de difamación antiarandista, pues en semejante albañal mojaron sus péñolas cuantos autores-extranjeros, y también españoles-escribieron más tarde con ánimo de vilipendiar la memoria del aristócrata aragonés.

Resulta, pues, innecesario repetir aquí lo que tan eruditamente expuso en su dia el Prof. Ferrer Benimeli. Esto no obstante, me permito insinuar de pasada, que si este autor alude en su obra a las personas de cuyo consejo y ayuda se sirvió Aranda para redactar su Denuncia al público del Viaje por España, y refutar con este escrito el miserable libelo del falso marqués de Langle(141), pasa por alto el nombre de Heredia, sin citarlo, en- 
tre tales colaboradores, detalle que no tiene nada de extraño, si consideramos lo dado que era el graense a pasar inadvertido, y a ceder en favor de otros hasta la gloriola de un éxito momentáneo. Por lo demás, tampoco es muy difícil percatarse de que muchos párrafos de la Denuncia de Aranda, contemplan puntos históricos y materias canónicas, cuya exposición y comentario- "el reflexionar bien", al decir del conde-requerian la apoyatura erudita que podía suministrar el doctor Heredia.

Gómez del Campillo aporta un despacho de Aranda a Floridablanca, fechado el 28 de noviembre de 1785, por el que podemos seguir paso a paso la actividad desplegada por Aranda en todo este asunto. En él da cuenta el embajador español de sus gestiones ante los ministros franceses, así como de la carta que dirigió a los redactores del Journal de Paris, con el pseudónimo de «El verdadero Fígarow(142), para desacreditar al falso Langle, y conseguir que no sólo se prohibiera dicho libelo antiespañol, sino que su autor-quien fuese-fuera severamente castigadd143).

No le resultaba fácil a Aranda tascar la rabia que le hervía en las venas cada vez que salía de sus entrevistas con el conde de Vergennes, quien siempre se hacía de nuevas, respondiaendo fríamente que nada sabía del "affaire Langle», o remitiéndole al Guardasellos para que desgranara sobre él sus quejas y cuitas. Así lo hizo el conde después de su inútil visita a Vergennes el domingo 23 de octubre de 1875.

El Guardasellos le dio largas diciéndole que la Denuncia de Aranda, presentada por el procurador general, Mr. Séguier, se examinaría después de la fiesta de San Martín (11 de noviembre), fecha en que volvería a reunirse el Parlamento, una vez concluidas sus vacaciones anuales.

"El sábado 29 de octubre-escribía Aranda-, tomando por motivo el sinnúmero de ejemplares del marqués de Langle que se veían extendidos, y que apenas se hallaba quien tuviese mi Denunciación [sic], expresé a Mr. de Vergennes, como en amistad, que me desconsolaba, por sus resultas, semejante fruición de las gentes por cuanto era hablar mal de España. Se ciñó a sacudirse [mi observación], remitiéndome al Guardasellos, y con decirme que tambièn por su parte lo sentía»144).

Aranda se trasladó a Fontainebleau, para entrevistarse una vez más con el Guardasellos, quien le aseguró que muy pronto sería presentado en el Parlamento el expediente contra el libelo de Langle. "Yo-informaba el 
conde-debo hacer justicia al Guardasellos, pues lo he visto consecuente desde el principio de este asunto, y con una actividad invariable, que $\mathrm{Mr}$. de Vergennes ha estado muy lejos de tenerla. Yo denuncié a este Ministro, la entevispera de mi partida para España, en diciembre de 1783, el artículo de la Enciclopedia hecho por el Sieur Masson [de Morvilliers], y habiéndole hablado de esto a mi regreso, y recordándole en esta ocasión la insolencia de aquél, que ha quedado sin castigo, nunca ha salido de decirme otra cosa sino que ya se había corregido al Censor, y como muy contentito de que se hubiera tomado tal providencia.

"Hechas muchas reflexiones, he preferido en medio de la Denunciación [sic], y consiguientemente el enviar una carta al Journal de Paris, porque, como difícilmente puede salir a la luz obra más descabellada que el tal Viaje, puestos en limpio sus desbarros y fricciones, sirve mi escrito para contrarrestar cuanto [de] igual ubiesen leido anteriormente estas gentes, y para prevenir lo que en adelante se pudiese publicar de parecido, sacando al menos el partido de iluminar a los que tuviesen cuatro dedos de razón.

«El ridículo es el arma más fuerte en este país, y por eso ha ido [mi Denuncia] en este tono, pues si reflexionar bien (como ya alguno de ha apercibido) es una critica a la ligereza nacional, el ridículo les hará más impresión que ningún otro medio, si no en el momento actual, al menos cuando se resfrie el calor con que toman aquí cuanto es despreciar a los españoles $)^{(145)}$.

Aranda concluía su largo despacho con este párrafo, que es una denuncia de 10 más significativa. "Muy pocos de esta nación francesa- exclamaba - han vuelto de España haciendo justicia al pais, ni a sus gentes. Es una cosa que aturde el mentir cada dia de los hombres y de las mujeres, que son las que más hablan, por lo que les oyen. Creo que la nación francesa, aunque es la más vecina, y a la que ha inundado la España, es, o la que menos la ha examinado, o la que más se ha formado un sistema de menospreciarla, pues excepto poquisimos, de alto abajo, se explican uniformemente en los discursos y conversaciones más familiares, que es donde el hombre habla según su corazón»(146).

El Gobierno de Luis XVI acabó cediendo a las reclamaciones de Aranda. Tras la contundente requisitoria del procurador general, Mr. Séguier, el 
Parlamento de París expidió el 7 de febrero de 1786 un decreto, en virtud del cual se condenaban las tres ediciones del libelo de Langle, y se ordenaba que fueran quemadas públicamente por mano de verdugo. "El Arrêt de este Parlamento-comentaba Aranda-hará bien para sujetar escritorzuelos, y desengañar a las gentes que tenian el escrito [de Langle] por joli, plein de feu et d'esprit, amusant, charmant, rémpli de vérités, quoique l'auteur parût quelque fois avoir la tête chaude et des idées originales w147).

Al conseguir esta condena, el conde de Aranda se adelantó paradójicamente a la misma Inquisición española, que aún tardaría diez años en incluir el engendro de Langle en el Indice de libros prohibidos(148).

El 6 de marzo de 1786 escribía Floridablanca a Aranda: «Recibi las del 17 y 20 de febrero, en las que V.E. dice que el Parlamento de París condeno a las Ilamas el infame Viaje de España de Fígaro. La petición de los Fiscales contra él es, sin duda, elocuente, enérgica y bien fundada, y merece estimemos la justicia que nos hacen. Al principio creí que tal libelo haría en nuestras gentes el mal efecto que dije a V.E., pero según parece, los que lo han leido juzgan ser obra del más enèrgúmeno de todos los impostores furiosos y hambrientos de este país, que nos ha tomado por asunto de sus sátiras para socorrer su miseria»(149).

Estas líneas pertenecen al despacho oficial que el ministro de Estado dirigió al embajador Aranda; pero en la minuta, que sirvió de borrador a dicho despacho, se decía: "El Rey aprueba todo lo hecho por V.E. para que se retire de la venta y se condene el escrito del falso Figaro. Estos disgustos que nos dan esa Nación y su Ministerio, le pueden servir a V.E. de motivo para defender y excusar otras muchas cosas que aquí se hagan en asuntos más sólidos, por la indisposición general que, puede decirse, va formando y echando raíces en los ánimos españoles, a causa del menosprecio con que pública y secretamente nos tratan los franceses, siéndonos preciso a los Ministros contemporizar, contra nuestros mejores deseos, y suspender muchas cosas útiles a las dos Naciones (150).

A título de ministro, el "golilla» Floridablanca prefería contemporizar que dirimir los problemas a cañonazos; su pacifismo, y el estado de la nación española, le vedaban las soluciones belicosas. Pero si se leen con mediana atención los artículos de su Instrucción reservada (1787), en que denuncia sin tapujos la urdimbre de las relaciones hispano-francesas, 
puede percibirse con bastante claridad dónde empezaba su "política», y dónde terminaba su "amistad" con el gabinete de Versalles (o.c. págs. 25861, n. $^{\circ} 302-325$ ).

Si Floridablanca se mostraba a veces como «anglófobo», no era por instinto personal, ni por resentimientos históricos, sino forzado por una -asi llamada_ "francofilia", cuyos pesados compromisos (derivados de las conveniencias de España) le atenazaban, obligándole a bailar en la cuerda floja de una política contra la cual tenía sobrados motivos de queja. Para más insidia, el ministerio francés convertía sus yerros en agravios, y se adelantaba a prostestar-el que pega primero, pega dos veces, y después ya veremos-, en lugar de reconocer su despotismo, y la artera intención de sus manejos antiespañoles.

Refiriéndose a este proceder del Gobierno francés escribía Floridablanca a Aranda: "En la suya del 27 del pasado refiere V.E. la conversación que tuvo con el conde de Vergennes, sobre los asuntos de la expedición [de España] contra Argel, y los casamientos de nuestros Infantes con los de Portugal, repitiendo en ella la frialdad con que suponen ahi tratamos aquí las cosas de Francia. Manifestó ese Ministerio mal humor, y nos parece que en parte pudo ser verdadero, y en parte artificioso, porque nosotros no mostramos el nuestro, que está más bien fundado que el del Ministerio Francés.

"Para formar queja de lo que nosotros hacemos, es necesario suponer que el Rey de España no tiene la misma obligación que cualquiera otro Soberano de atender a su dignidad, a su decoro, y a la seguridad de sus súbditos; que no debe mirarlos con predilección, ni procurar que se extienda su industria y comercio, y que no es cosa razonable que en algún modo procuremos enmendarnos de la indolencia que se nos atribuye, y desmentir la pintura ridícula e ignominiosa que cualquier necio escritor se toma la licencia de hacer de nosotros, y de nuestro Gobiernow(151).

$\mathrm{Ni}$ las buenas intenciones de Floridablanca, ni los empeños de Aran$\mathrm{da}$, en orden a "contener el furor de una plumas tan desatinadas" como las de Masson o Fleuriot, sirvieron de mucho para mejorar el clima de las relaciones entre ambos países limítrofes, y cambiar mínimamente la opión antiespañola de algunos franceses, que pasaban por personas cultas y civilizadas, pues dos años más tarde, escribiendo Floridablanca a J. N. de 
Azara, embajador de España en Roma, le decía confidencialmente: "Yo no sé qué diablos se les ha metido en la cabeza a algunos franceses del Cuerpo Diplomático, que a pesar de nuestro interés en mantener pública y secretamente la amistad entre ambas Naciones, parece que estudian los medios de mortificar e indisponer los ánimos de los Ministros españoles. Es desgracia de ellos, más que nuestra, y lo peor es que para sostener sus locuras inventan patrañas o las escriben a su Corte. Si aquí estuviera sentado en mi silla [de ministro] otro de menos cachaza, ya hubiera ido al diablo con todos los diantres la porqueria de su amistadm(152).

De nada valieron todas estas protestas y representaciones, pues todo continuó en el mismo pie que antes; los franceses, en general, pues nunca faltaron-ni faltan-las excepciones, siguieron considerando a España como un país africano, y tratando a los españoles peor que a zipayos. Con el tiempo las cosas cambiaron de grado, pero no de estilo; en el siglo XVIII zaherian a España con libelos difamatorios, en el XX quemando camiones cargados de hortalizas.

REGRESO DE HEREDIA A ESPAÑA.

El clima de París no debió de sentar nada bien a la delicada condesa de Aranda, quien desde otoño de 1784 comenzó a notar los síntomas de un "humor erisipeloso". Los baños de Luchon y de Bagnères de Bigorra le produjeron un notorio alivio, pero esta mejoria apenas duró un año, y en octubre de 1786 tuvo que regresar a España definitivamente(153).

Aranda acompañó a su mujer hasta Bayona, pero al volver a París debió sentirse tan solo-la embajada le parecía tan vacía sin ella-que a las pocas semanas de separación presentó a Floridablanca su dimisión, solicitando abandonar el cargo que ocupaba. Como no recibió respuesta de Madrid, repitio su demanda de retirarse, basando la petición uen el aprecio - decía-que yo hago de mi mujer, la señora Embajatriz, para desear vivir en su proximidad, en el objet[iv]o de haberme casado por segunda vez, y ponerlo en incertidumbre con la separación de las personas, y en los años que van aumentadon(154). 
El conde seguía preocupado con la idea-tan estamental como biológica-de dar un heredero a la Casa Aranda (tal había sido el objetivo de su segundo matromino), y, aunque nunca pudo conseguir esta ilusión, se le hacia cuesta arriba permanecer solo en París, como «un fraile de Marte". Cuando Floridablanca le escribió el 12 de febrero de 1787, haciéndole saber que Carlos III aceptaba su renuncia, el conde exultó de gozo, y respondió a vuelta de correo dando al monarca las más expresivas gracias(175).

La noticia del retiro de Aranda causó cierta sensación, y se extendió rápidamente por las embajadas de España en Europa. Como ocurre en tales casos, unos alababan la decisión del conde, y otros opinaban por el contrario que debia continuar en Paris. Su sucesor Fernán Núñez era de los primeros. Intimo de Aranda desde hacía años, él había sido el principal casamentero que indujo al conde a contraer un segundo matrimonio, cuyos frutos, en orden a asegurar la continuidad del apellido Abarca de Bolea, anteponia a otras razones o conveniencias de alta política. "Mi venerado Agüelo y amigo-le decía-, nuestro duque del Infantado, que empujado por su hijo ha llegado antes de ayer aquí, me ha entregado el apreciable pliego de V.E. Lo que yo deseo es que V.E. sea pronto padre, y que siga en esto nuestro buen ejemplo. Mi mujer, recién parida, dice lo mismo, y el sábado la llevo de nuevo a Yssy [?], para que se recobre y se divierta con nuestro Infantado y su familia que, como sabe V.E., ha sido siempre la mia. Se la dará descanso, pues ya se acaban los agüelos [abuelos], y, lo que es más, aumentan los años, y hace falta el suco vital, que en los Colegios se empieza a desperdiciar pronto. Estos soberanos [de Francia] son los padrinos de la criatura, pero aún pasarán algunos meses antes [de] que se haga la ceremonia del bautismo ${ }^{156)}$. Como puede verse, el conde de Fernán Núñez, típico aristócrata del Antiguo Régimen español, se expresaba movido por razones patrimoniales y de amistad personal.

En cambio en embajador J. N. Azara, asiduo corresponsal de Aranda, pertenecia al otro grupo. Solterón impenitente como Heredia, y libre de la preocupación de asegurar la continuidad de su patrimonio, daba preferencia a las razones políticas, y opinaba que la diplomacia podía armonizarse con la biología. En fin, cualquier cosa antes de volver a España(157). 
Bastante antes de que Carlos III aceptara su dimisión, Aranda había escrito a Azara, en plan de consulta, comunicándole sus intenciones de volverse a Madrid, para reunirse con su mujer, restablecida por los aires de Castilla. Sin pensárselo dos veces, Azara le respondio con las siguientes palabras: "Vamos a la cuestión médico-legal que V.E. me propone. Si la parte enferma [la condesa], que ha curado con la mutación de aires y clima, se hallase en el confín de Europa y en tierra de cristianos, desde luego diria que fuese V.E. a piés descalzaos a unirse con tal persona, para no pensar más que en hacerle un par de hijos en paz y quietud; pero como, por desgracia, la tal persona está metida en tierra de moros con peluca, con frac, con espada y con rosario, aconsejo a V.E. a reunir son menaje donde ahora está V.E., y a renunciar al Alcorán y a los Pirineos. Yo, sin tener hijos que hacer, tengo hecha renuncia formal a toda la Morerías(158).

Una vez que la renuncia de Aranda y su retorno a España se hicieron noticia oficial, Azara le escribió en tono amistosos: «Si V.E. piensa que yo me alegro de su retiro, se engaña, porque lo desapruebo francamente, y a estar en mi mano lo habria impedido. Esto no quita el que nadie en el mundo se interese tanto como yo en la satisfaccion personal de V.E. De su carta entro en sospecha de que piensa retirarse aun de Madrid, aunque no lo dice claro, y esto me disgusta aún más, pues para vivir tranquilo, y aun para procurarse un heredero, no creo que sea necesario hacerse anacoretax(159).

A los pocos dias le respondio Aranda con una líneas confianzudas, cuyos giros y alusiones revelan de rechazo la salud mental y el humor que se gastaban aquellos hombres del XVIII. "Hablemos de Somontanos, Señor Paisano: Desaprueba VS mi retreta [sic] del gran mundo, y yo me la apruebo cada día más. No piense VS que yo me incline a vivir entre carrascas, y en plan montaraz; no tendría valor para ello, no por mi, que miro todo parejo, sino por una linda y amable criatura que es mi compañera, y deseo que habite entre racionales. Yo puedo, a temporadas, irme a derecha e izquierda, a ver mis cosas; y entre ellas, y la tranquilidad casera, el trato de los amigotes, y un puchero con sus alrededores, pasarme una vida canonical; libros, y a ello, para las horas y ratos propios de manejarlos; sus capucetes propter salutem, en tanto que se pueda, salgan o no cuatrillizos, al menos divertirán; y con estas tonterias se reirá VS de pronto; y yo lo pasaré 
bien después. Fernán Núñez estará aquí a fines de septiembre, y a su llegada partiré yo. Amigo, mi puño escribe más claro que el de VS, y esto probaría que en otras fuerzas también me hallaré en mejor estadow(160).

No caigamos, sin embargo, en la ingenuidad de creer que Aranda miraba "todo parejo", y pensaba llevar en España una vida tan idílica y tan "secundum naturam" como la que pintaba en sus confidencias. Nada más lejos de ello. La ociosidad no le iba a su genio, y si le urgía el «procurarse un herederos - que no le fue dado--, con no menor ardor deseaba desbancar a su rival político el "golilla" Floridablanca, meta que alcanzaría, aunque efímeramente, pues su interinato en la Secretaría de Estado sólo duró nueve meses escasos.

Aranda fue ventilando los asuntos que le concernian como embajador; era una manera de ir cortando las amarras que le ataban a París, y de preparar las cosas para recibir a su sucesor, el conde de Fernán Núñez, que llegaría el 7 de octubre a la capital francesa.

Un mes antes de que Carlos III le concediera licencia para retirarse, Aranda se presentó en Versalles acompañado de Heredia, para concluir de una vez el Tratado de Límites, establecidos entre los dos paises, tras largas negociaciones, en la frontera franco-navarra de los Alduides(16i). La firma tuvo lugar el 16 de enero de 1787, y puede decirse sin exageración que este acto oficial fue una de las últimas actuaciones del conde de Vergennes, en calidad de ministro de Asuntos Exteriores, ya que falleceria el 12 de febrero, sucediéndole en el cargo el conde de Montmorin, antiguo embajador de Francia en Madrid.

También para Heredia este acto constituyó su última representación diplomática en Francia, pues en vista de que su jefe Aranda había impetrado el retiro, creyó llegado el momento de volver a su patria, a ocupar la plaza de Consejero de Guerra. Así se lo comunicó a Floridablanca, y proponiéndole sus planes le decia: «Pienso salir de aqui hacia el 20 de abril, y haré mi viaje por Cataluña, para ver en Aragón a los parientes que me han quedado, y a los nuevos que me han nacido, con treinta años cabales que hace que salí de mi casa para esa Corte. Esto retrasará mi llegada ahí hasta fines del mes de juniow(162). 
Floridablanca le respondió dando su total conformidad, al tiempo que le prevenia dos cosas; una, que el rey le habia concedido 250 doblones de oro, como ayuda de costa, para enjugar los gastos del viaje; y otra, que don Domingo Iriarte, secretario de la embajada española en Viena(163), sería su sucesor, pues se le habia destinado a París con el mismo empleo.

Heredia abandonó la capital francesa el 26 de abril de 1787, y siguiendo el itinerario que se había trazado, se detuvo en Graus. Después de "treinta años cabales" de ausencia, volvía a su villa natal convertido en un personaje de vitola internacional. Venía de París, donde había residido catorce años, y se dirigia a Madrid, para ocupar un importante cargo en la Corte. Además, había sido enviado a Londres para desempeñar allí una alta misión de Estado, y habia viajado por media Europa. ¡Cuántas cosas interesantes podía contar aquel diplomático, enterado de tantos secretos y conocedor de tantas curiosidades!. Su llegada a Graus, a bordo de un elegante "roulier", tuvo que constituir todo un acontecimiento, si tenemos en cuenta las pocas cosas que ocurrian entonces en la monotonía cotidiana de aquel villorrio, aterido de lejanía, muchos de cuyos vecinos morian sin haber pisado nunca la vecina Barbastro, ni haber estado jamás en la ciudad de Huesca. No es, pues, dificil imaginar, sin necesidad de hacer novela, el alborozo de sus familiares y parientes, y el legítimo orgullo con que le agasajaron durante su corta estancia entre ellos.

No sabemos si Ignacio de Heredia, al pasar de ida o de vuelta por Barbastro, se encontró con tres de sus hermanas que vivían en dicha localidad: Ignacia y Raimunda, en el convento de las religiosas clarisas, y Antonia, casada con el caballero don Pedro Garcia Aolva, regidor perpetuo de la misma ciudad; como ignoramos asimismo si se desplazó a verlo su hermana menor, Manuela, que vivía en el lugar de San Rcmán (Morrano, Huesca), casada con el infanzón don Antonio Subiza y Codol, barón de Abella y señor de Monte de Carrén(164). Lo que si podemos asegurar es que Ignacio, cuyos padres habían fallecido ya, pudo abrazar en Graus, donde residian, a sus otros dos hermanos: Antonio, clérigo beneficiado y vicario de las parroquias de la villa; y Vicente, cuya personalidad merece un breve comentario aparte.

El infanzón Vicente de Heredia y Alamán, señor de Perilla, donde había nacido, siguio en un principio los pasos de su hermano mayor 
Ignacio, ya que también se hospedó, durante algunos años, en el Colegio de San Vicente de Huesca, y, después de doctorarse en Leyes, se dedicó a la docencia, llegando a ser catedrático de jurisprudencia en la Universidad Sertoriana. Al morir su padre, Vicente heredó el mayorazgo de la familia, circunstancia que le obligó a dejar la cátedra, y a establecerse en la casa solar de Graus, donde en mayo de 1786-hacia, pues, escasamente un año-contrajo matrimonio con doña Josefa Godino y Lobera, natural de la villa de Ateca (Zaragoza)(165). Al llegar a Graus su cuñado Ignacio, esta señora de genio activo se hallaba encinta, y llevaba el embarazo tan adelantado, que el 16 de junio de 1787 dio a luz a su primogénito Pablo(166).

El «ilustrado" Vicente de Heredia, hombre de "mucha literatura" y entendido en cuestiones de Historia Natural, era un espiritu curiosos y a la vez práctico. Sabia mezclar lo útil con lo dulce, y la administración de su patrimonio, que vigilaba con atención, le dejaba tiempo para escribir, con letra regular-característica de los Heredia-, lo mismo unas Memorias genealógicas de su propia familia, que tratados sobre el carbón de piedra y la producción del betún, o disertaciones eruditas sobre la extinción de las plagas de langosta, la explotación de las Salinas de Naval (Huesca), y el cultivo racional del almendro en la vega del río Isábena.

Por lo que atañe a su faceta de hombre público, Vicente de Heredia llegó a pertenecer a la Real Sociedad Económica Aragonesa de Amigos del Pais, de la que fue individuo de número; y siendo alcalde de Graus colaboró activamente en la guerra de España contra la convención de Francia (1793-95). Desde el cuarte general de Huesca o de Jaca le llegaban órdenes perentorias dictadas por el príncipe de Castelfranco, general en jefe del frente aragonés(167): hoy se trataba de proveer mil raciones para la tropa, 0 de reunir quinientos peones para cosechar las mieses de las zonas fronterizas(118); mañana era cuestión de enviar doscientas camas, con ropa, al Hospital de Benasque (Huesca)(169), cuando no de alojar «a la mayor brevedad y ganando instantes" a cuatrocientos soldados, enviados por el comandante general de artillería don Juan de Jourtén(170), o de disponer, "con toda brevedad, que pasasen a la frontera ochocientos hombres de los alistados, para ponerse a las órdenes del duque de Granadax(171). 
Por decreto del 14 de junio de 1799, Carlos IV nombró a Vicente de Heredia caballero pensionado de la ilustre Orden de Carlos III, y el agraciado recibio la investidura en la iglesia de San Cayetano de la ciudad de Zaragoza(172).

Vicente de Heredia ya no era alcalde de Graus cuando, el mes de enero de 1810, el general francés Suchet entró en la capital de Huesca. Acto seguido, las tropas invasoras se desparramaron por la provincia, y los Heredia-como las demás familias y vecinos de Graus-se vieron obligados a recibir en sus casas a un determinado número de soldados extranjeros; en el Ayuntamiento de la Villa se expendían las cédulas de alojamiento, que incluian "cobijo, cama, lumbre, agua, aceite, vinagre, sal, pimienta, mantei y cuchillox(173). Los soldados franceses se instalaron a su antojo, y si bien no hecharon a la calle a los Heredia, como sucedió con otras familias, al marcharse dejaron la casona patas arriba y hecha una verdadera miseria.

Aunque el estado de guerra continuó en otras zonas hasta bien entrado el año 1813, fecha en que las tropas francesas comenzaron a salir de España, sobre Graus y su comarca se habia extendido con anterioridad un relativo arco-iris de tranquilidad, a juzgar por las cartas que Vicente de $\mathrm{He}$ redia escribía a su hermana viuda Manuela, residente en el lugar de San Román, y a su propio hijo Pablo(174).

Cerraremos este recuento de datos biográficos señalando que el 30 de octubre de 1813, las Cortes Generales de Aragón eligieron a Vicente de Heredia diputado a Cortes. Este nombramiento le obligó a desplazarse a Madrid, donde permanecería hasta el 7 de mayo de 1814(175).

Pero retrocedamos a la primavera de 1787, época del paso de su hermano Ignacio por Graus, camino de la Corte, a donde llegaría finalmente en agosto de ese mismo año176). No es disparatado suponer que el viajero trajo de París algunos regalos para obsequiar a sus familiares, y que en las conversaciones de sobremesa hubo sin duda más de un recuerdo para el hermano menor, Francisco Javier, desterrado en Bolonia. Esta fue la última visita que hizo Ignacio a los suyos en su villa natal, y ésta fue también la primera vez que se separaba profesionalmente del conde de Aranda, después de haberlo servido, y trabajado junto a él, más de cinco lustros. 
Heredia sólo llevaba consigo los objetos más delicados, y las cosas más imprescindibles para el viaje; el resto-lo que podriamos llamar «el gran matalotaje"-lo habia facturado por mar. Una parte de este equipaje estaba constituido por los cajones y baúles que contenian los libros comprados por él en París.

Cuando Heredia fue nombrado Consejero de Guerra, en febrero de 1783, pensó seriamente en regresar a España, para ocupar dicha plaza en Madrid; si no lo hizo fue, como dijimos, porque Floridablanca le recomendó permanecer de momento al lado de Aranda, que lo quería tener junto a sí, y además así convenía al real servicio. Esto no obstante, que la idea de Heredia, de tornar entonces a su patria, no era una veleidad sino una decisión formal, se deduce de la carta que dirigió al propio Floridablanca, pidiéndole licencia para enviar sus libros a España. El ministro de España se lo concedió, y con este fin escribió al entonces ministro de Hacienda, don Miguel Múzquiz, las siguientes líneas: «Envia D. Ignacio de Heredia sus libros y demás cosas a desembarcar a Bilbao, y S.M. el Rey resuelve que se permita entren, aunque estén encuadernados, sin embargo de la Real Cédula que lo prohibe, mediante ser para uso propio y no para comerciow ${ }^{177)}$.

En la presente ocasión, el trámite fue idéntico; Floridablanca se dirigió al ministro de Hacienda, López de Lerena, comunicándole de orden del monarca, que se sirviera avisar a los aduaneros, y familiares de la Inquisición de Bilbac, dieran paso franco al equipaje de Heredia, y a sus libros, "aunque estuvieran encuadernados», cuando llegaran a dicho puerto(178).

Sin meternos ahora a explicar las razones del hecho, sabemos que los libros extranjeros se habian convertido entonces en una mercancia peligrosa, y por ende muy vigilada por el Santo Oficio; tal vez por eso se contrabandeaba con ellos brava y pintorescamente, pues no era infrecuente «poner en los tejuelos un rótulo muy diverso del verdadero contenido del libro, ni era caso raro que las cubiertas de un San Basilio, o de un San Agustín, sirvieran para amparar volúmenes de la Enciclopedia". Con estas palabras señalaba Menéndez Pelayo un hecho real, que solía darse en ocasiones, pero exageraba a todas luces cuando añadía a continuación: «No exagero si digo que hoy mismo están inundadas las bibliotecas particula- 
res de España por ejemplares de Voltaire, Rousseau, Volney, etc., la mayor parte de las cuales proceden de entoncesw'179).

Si en la estepa cultural de la España del XVIII había-relativamentemuchas o pocas bibliotecas particulares con obras de este tipo, es una incógnita global que todavía no ha sido despejada por los eruditos e historiadores. Con nuestra modesta aportación sólo podemos decir que no fue éste el caso de la biblioteca de Ignacio de Heredia.

Como Heredia no era un contrabandista, ni un picaro, ventiló este asunto con toda legalidad y honradez. Pero con igual seriedad procedian otros «ilustrados españoles, a la hora de regresar a su patria trayendo los libros que habian adquirido en sus viajes por el extranjero. Me permito decir, a este respecto, que al hilo de mis lecturas me he topado fortuitamente con dos casos: el de otro graense ilustre, don Eusebio Bardají(180), y el del ya citado A. J. Cavanilles(181), pero-lógica y necesariamente-este trámite adminstrativo, impuesto por la ley, tuvo que repetirse infinidad de veces, en las aduanas españolas, a lo largo del siglo XVIII.

La lista de libros comprados por Heredia, que reproducimos a continuación, nos permite conocer el contenido material de su biblioteca particular, y nos muestra al mismo tiempo la amplia gama de sus tendencias y aficiones culturales. Es la típica «librería» de un «ilustrado» español del siglo XVIII, y su nota más saliente es tal vez el ancho espectro de sus titulos. No pocas gentes sentian entonces-como ahora-una gran curiosidad intelectual; este impulso brotaba de una fuente única, pero se extendía a muchos campos, $y$, a poder ser, pretendía abarcar todos los ramos del saber. Por eso, en la biblioteca de Heredia encontramos obras antiguas y modernas-quiero decir, clásicas y coetáneas a él-de los más variados géneros.

Desde un punto de vista puramente cuantitativo, se trata de un lote nada despreciable de 247 títulos que, salvo error u omision, hacen un total de 555 volúmenes. En muchos casos, Herdia hace-como puede comprobarse-una ficha casi completa del libro; en cambio en otros, se contenta con anotar el título de la obra, omitiendo otros datos imprescindibles para su identificación, de suerte que a nosotros-quizá por carecer de repertorios y subsidios bibliográficos ad hoc-no siempre nos ha sido posible identificar el nombre del autor, o fijar el lugar y la fecha de su edición. 
En cuanto al precio de los libros-Heredia no escatimó el dinero-, podemos establecer un baremo diferenciador, cuya simplicidad hace que, salvo aigunas excepciones, pueda ser aplicado a todo el conjunto de la lista. Tal baremo consiste: en que Heredia pagaba con francos los libros publicados fuera de Francia, y escritos en italiano o en inglés (en algún caso también en francés); mientras que se valía de libras y sueldos(182) para adquirir las obras impresas en Francia, y escritas naturalmente en francés.

Por lo que atañe al aspecto cualitativo, mi comentario será muy somero, pues, aun a trueque de pasar por simplista e incluso por rudimentario, sólo tendré en cuenta, como es obvio, la orientación general de las materias abarcadas por los títulos de los libros, prescindiendo de los ramos del saber que no aparecen en la referida lista; es decir, que me fijaré en el contenido global de lo que se nos ofrece, y no en lo que se echa de menos o se nos antoja que falta.

Por tanto, nadie espere encontrar aqui un cómputo aritmético, merced al cual se constate el número exacto de libros que tratan de una determinada materia; consecuentemente, tampoco trazaré un diagrama estadístico de las proporciones en que está representada cada rama de la ciencia, porque resulta perfectamente supervacaneo-dado que fuera posible_saber a la luz de semejantes cálculos, si la inteligencia de Heredia estaba seis veces y media más capacitada para las Matemáticas que para la Paleografía, o si sólo el "dos con trece por ciento" de su materia gris daba cabida a los rudimentos de Ocenografía. No se trata de ninguna broma; estoy hablando muy en serio, pues durante algún tiempo-de reacción pendular-se ha hecho pasar a la Historia por las horcas de la "cliometría", y se ha operado encarnizadamente como si pudiera rastrearse la ideología-fascista, claro está-del duque de Olivares, a través de la curva decenal de precios de la fanega de trigo en el mercado de Medina del Campo. Por fortuna, parece que están en regresión ciertos trabajos de investigación histórica, muchas de cuyas páginas se asemejaban más bien a unas tablas de logaritmos.

Una lista de libros no es, ya se entiende, ningún laboratorio paidométrico; por lo mismo, sus títulos únicamente permiten captar algunas tendencias generales y detectar ciertas preferencias intelectuales de su dueño. En el caso de Heredia, estas inclinaciones-vistas desde el ángulo 
de la ortodoxia católica-eran tan inicuas, que dificilmente podían alarmar a los sabuesos de la Inquisición española. A mi juicio, se trata menos de la biblioteca de un verdadero «ilustrado» del XVIII, que de la "librería» de un honnête homme, cuya vida profesional-y social-discurria por los cauces propios de un diplomático español del Antiguo Régimen. De ahí su interés por la cuestion de Gibraltar, por el Derecho Internacional y el Natural, o el comercio de Inglaterra y su rivalidad con Francia.

Es cierto que en la lista de Heredia aparecen obras de algunos autores-como Rousseau (.$\left.^{\circ} 210\right)$, Voltaire ( $\left.n .^{\circ} 244-46\right)$, d'Alembert ( $\left.n .{ }^{\circ} 11\right)$ o el abate Raynal (n. $\left.{ }^{\circ} 199\right)$-, cuya peligrosidad estaba archidenunciada por todos los Expurgatorios. Pero, ¿de qué obras se trata?. De las más inofensivas, como puede verse. En cambio brillan por su ausencia los libros materialistas de Helvétius, La Mettrie o el barón d'Holbach, así como la literatura erótica de Choderlos Laclos, y de Diderot, o la basca de Crébillon (hijo) y de otros plumíferos, cuyos escritos pornográficos corrían impunemente por París. La misma Enciclopedia (.$^{\circ} 82$ ) sólo aparece representada en forma de fascículos, que contenían artículos dedicados por Diderot al estudio y divulgación de las artes mecánicas.

Las obras consagradas al conocimiento de las "ciencias útiles" superan en número a los tratados especulativos, aunque tampoco faltan en la lista libros filosóficos. Si hay una nutrida presencia de los poetas y escritores de la antigüedad clásica, se echa en cambio de menos a los historiadores greco-latinos, como también a Cicerón, pero ello se debe sin duda a que Heredia creía poder encontrar fácilmente en España las obras de estos últimos autores.

La lista en cuestión nos ofrece asimismo la réplica de otras propensiones de su propietario. No se olvide que Heredia era un catolico practicante, un español cultivado, con fuertes vetas de humanismo, una persona que vigilaba su salud corporal, y un discreto hombre de mundo. Nada tiene, pues, de extraño y sí mucho de lógico que, dada su formación universitaria, procurara tener a su vera obras de Teología y de Moral, de Sagrada Escritura y de Historia Eclesiástica. Los libros de mundologia le daban reglas y consejos sobre el modo de comportarse en público y de contar anécdotas en sociedad, $y$ le indicaban el método para curarse de los cuernos ( $n{ }^{\circ}$ 211), dolencia muy frecuente en París, y en las afueras de Francia; 
y en los tratados de Medicina-ciencia de la que Heredia hacía mucho caudal-se iniciaba en el conocimiento del cuerpo humano y sus enfermedades, o buscaba recetas para regular su régimen dietético, no menos que para sacar provecho a la ociosidad, o modular con sagacidad la sonoridad de las flatulencias ( $n .^{\circ} 65$ y 143). Tampoco se descuidaban la Lógica y las Matemáticas, disciplinas cuyos principios complementaba Heredia con tratados de ingeniería y de Física.

Concluiré este análisis somero con dos puntos que asoman tímidamente en el horizonte de las aficiones culturales de Heredia. Uno de ellos se refiere a los jesuitas $\left(n .^{\circ} 117,133,233\right)$, cuyo recuerdo-en pro o en contra-parece que no se le borraba; y el otro, a su curiosidad por el misterioso mundo de la magia y de los sueños ( $n .^{\circ} 34,85$ y 138), que entonces hacia furor, y tenian en ascuas al "tout Paris".

La baronesa d'Oberkirch (1754-1803), dama de origen alsaciano, pasó largas temporadas en Paris, y en junio de 1784 fue presentada oficialmente en la Corte de Versalles. Muy atraida por el maravillosismo, y harto aficionada a la magia, trató de cerca al médico austriaco Mesmer-que hacia curaciones portentosas con su varita-, y conoció personalmente al impostor Cagliostro, de cuyo maléfico influjo supo, sin embargo, sustraerse a tiempo. La baronesa, que se las daba de hábil echadora de cartas, cuenta en sus interesantes Memorias que el $1 .^{\circ}$ de febrero de 1786 tuvo lugar una sesión de hipnotismo en casa de un amigo suyo residente en París. A ella asistio, según podía recordar, "un jeune secrétaire de l'eambassade d'Espagne, un [tel] comte d'Arandai, el cual estaba pálido y temblaba de piés a cabeza a causa de las palabras de la "medium", una muchacha judía que, en su sueño hipnótico, había revelado en voz alta, delante de todos, ciertos episodios secretos de la vida del referido secretario de embajada, al que la joven no conocia en absoluto, pues era la primera vez que lo veia(183).

Parece que la baronesa sufría cierta confusión a la hora de evocar sus recuerdos, y que en el caso presente hablaba por reminiscencias, pues aunque menciona explicitamente el nombre de Aranda, añade a renglón seguido, no sin cierta contradicción, que, en cuanto ella podía rememorar ("autant que je puis me souvenir"), se trataba de "un joven secretario de la embajada de Españan en París. Ahora bien, en 1786 Aranda era casi un 
anciano, y en cuanto al secretario Heredia, tampoco era ya ningún mozalbete, pues frisaba los 58 años de edad, a no ser que su organismo y su rostro conservaran todavia un aspecto juvenil, detalle que desconocemos por completo. En cualquier caso, debió ser algún miembro de la legación española quien asistió a la sesión de hipnotismo, celebrada en casa de Mr. Puységur, oficial francés que habia luchado contra los ingleses en el asedio de Gibraltar, y no es improbable que la baronesa trastocara los personajes a la hora de evocar el incidente, pues este tipo de hechos semiportentosos eran entonces moneda corriente en la capital francesa(184).

Aranda debió de ceder a Heredia algunos libros de su propiedad ( $n .^{\circ}$ 181 y 182), y sabemos que, al volver a España, el conde dono otros muchos suyos a la Real Sociedad Económica Aragonesa de Amigos del País, de la que era miembro distinguido(185), pero ignoramos a dónde fue a parar, o quién heredó, la "librería" de Ignacio de Heredia y Alamán, cuando éste falleció en Madrid hacia 1797. 


\section{LISTA DE LOS LIBROS QUE DON IGNACIO DE HEREDIA HA COMPRADO EN PARIS}

Nota. Los libros que llevan la letra $B$ no están encuadernados.

1.-ACHARD, Cl. F., Dictionnaire de la Provence et du Comté Venaisin. Paris, 1785, 2 vols. in-8. ${ }^{\circ}$.

2.-ACOSTA, M., Histoire des revenus ecclésiastiques. Utrecht, 1697, 1 vol in-12., 1 libra y 6 sueldos.

3.-Acta Litteraria Upsaliae. Estocolmo, 1773-75, vols 1 y 2.

4.-Acta Physico-mathematico-bothanico-medica Helvetiae. Basilea, $1751-1777,8$ vols in fol.

5.-ACURIA, P. de, Relation de la Rivière des Amazones. Paris, 1682, 2 vols in-12., 2 libras.

6.-AGuesseAU, H. F. de, Ouvres. Yverdun, 1772-75, 2. ${ }^{\mathrm{a}}$ ed. 12 vols in-12:.

7.-ALBerRTI, G. A., Pirotechnia ossia Trattato di fuochi d'artifizio. Venecia, 1 vol in 4 . .

8.-ALBIN [ALBINUS], B. Sigfrid, Tabulae squeleti et musculorum corporis humani. Lión, 1747, 1 vol in folio con 10 láminas.

9.-IDEM, Tabulae ossium humanorum. Leyden, 1753, 1 vol in fol.

10.-ALDRICH, H., Artis logicae compedium. Oxford, 1750, 4. ${ }^{a}$ edición, 1 vol in-8:.

11.-ALEMBERT, J. le ROND de, Opuscules mathématiques. Paris, $1782-80,8$ vols in-4. con figuras.

12.-ALFIERI, V., L'America libera. Pisa, 1784, 1 vol in-8..

13.-ALVAREZ DE COLMENAR, A., Délices de l'Espagne et de Portugal. Leyden, 1707, 5 vols in-12., 12 libras y 19 sueldos.

14.-AMIANO MARCELINO, Oeuvres. Trad. de G. de Moulines. Lión, 1778, 3 vols in-4․

15.-Analyse des principes du Droit François, Sf. ni lugar, 1 vol in-8. , 1 libra y 6 sueldos.

16.-Anecdotes du Comte Duque d'Olivares. Paris, 1772, 1 vol in-12.', 2 libras. 
17.-Anecdotes litteraires ou Histoire de ce qui est arrivé de plus singulier aux écrivains français depuis le renouvellement des lettres. La Haya, 1776,4 vols in-12. .

18.-Anecdotes secrètes du XVIII siècle. Londres, 1783, 1 vol in-8. .

19.-Année Littéraire. Paris, 1776-1786, in-12:. Editado por Fréron hijo, Grosier, Hérivaux y otros publicistas.

20.-ANQUETIL DUPERRON, A. Hyac., Législation orientale. Amsterdam, 1778,1 vol in-4․

21.-ANTONIO, C. de, Pharmacopea Lusitana. Coimbra, 1714, 1 vol in-4.. 22.-ANVILLE, J. Bap., Atlas Général. SI ni fecha, 1 vol in fol.

23.-IDEM, Mémoire sur la Chine. París, 1776, 1 vol in 8. .

24.--Apocalypse expliquée par l'histoire ecclésiastique. París, 1701, 1 vol in-4. .

25.-Apologie des fainéans, ou défense de l'oisiveté. París, 1665, 1 vol in-4: . 26.-APULEYO, L., Les métamorphoses ou l'asne d'or. París, 1786, 2 vols in-8. . ed. bilingüe en latín y francés. Traducción al francés por J. F. Bastien.

27.-ARDUINO, P., Memorie di osservazioni e di sperience sopra la coltura [sic]e gli usi di varie piante. Parma, 1766, 1 vol in-4. .

28.-ARENA, F., La natura e coltura [sic] de'fiori. Cosmopoli, 1771, 2 vols in-4., con láminas.

29.-ARISTOFANES, Théâtre de [...] en français. París, 1784, 2 vols in-8. , trad. al francés de $L$. Prinsinet de Sivry.

30.-AUBERY, L., Mémoies pour servir à l'Histoire de Hollande et des autres Provinces Unies. Paris, 1734, 1 vol in-8.. Prohibido en Bélgica.

31.-BARBERINI, Poemata. Paris, Ed. de Louvre, 1 vol in fol., 6 libras.

32.-BAREAUX, Abbé, Les quatre poétiques. Paris, Sf. 2 vols in-4., 7 libras.

33.-BARRELIER, Jac., Plantae per Galliam, Hispaniam et Italiam observatae. Opus posthumun, curavit A. de Jussieu. París, 1714, 1 vol in folio con figuras.

34.-BEAUMONT, John, Treatise of Spirits, Apparitions, Witchcrafts an other magical Practices. Londres, 1705, 1 vol in-8..

35.-BERTHOUD, Ferd., Essai sur l'horlogerie. París, 1786, 2 vols in-4!, 36 francos. 
36. - BIÈVRE, Marquis de, Almanach des calembrours. Paris, 1771, 1 vol in-8. .

37.-BOECIO, A. M., De consolatione. Paris, 1771, 1 vol in-12., edic. bilingüe, traduc. al francés por L. Colesse.

38.-BOILEAU, Nic., Lettres. París, Sf. 3 vols in-12., 3 libras y 6 sueldos.

39.-BOlingBROKE, H., Pensées. Paris, Sf. 1 vol in-12.', 1 libra y 6 sueldos. 40.-BONNET, Ch., Contemplation de la Nature. París, 1764, 2 vols in-12?, 3 libras y 4 sueldos, B.

41.-BOSSUET, J. B. Discours sur l'histoire universelle. París, Imp. ${ }^{a}$ Didot l'aîne, 1784,1 vol in-4․ .

42.-IDEM, Ouvres de la nouvelle édition. París, Sf. 6 vols in-4., 73 libras y 10 sueldos.

43.-BOULANGER, N. A., L'antiquité dévoilée par ses usages. Prólogo de D. Diderot. Amsterdam, 1772, 3 vols in-12., 36 francos.

44.-BOURGEOIS de CHASTENAT, J., Histoire du Concile de Constance. Paris, 1718, 1 vol in-4:, 4 libras.

45.-BOYER, J. Bap., marqués d'ARGENS, Lettres chinoises. La Haya, 1769,6 vols in-12․

46.-BUANET, T., Histoire de la Réformation Anglicane. París, Sf., 2 vols in-4., 4 libras y 16 sueldos.

47.-BUCHOZ, P. J., Le jardin d'Eden. Le paradis terrestre renouvelé dans le jardin de la reine à Trianon. París, 1783, 2 vols in folio con 147 planchas, 20 libras y 8 sueldos.

48.-BUFFON, J. L., Histoire naturelle générale et particulière. Paris, 1749-1767, solo 4 volúmenes de los 15 que constaba la edición.

49.-BULLIARD, P., Histoire des plantes vénéneuses et suspectes de la France. París, 1784, 1 vol in folio.

50.-BURLAMAQUI, J. A., Principes du droit de la nature et des gens. Ginebra, Sf.

51.-CAIRI, J. de, Essai sur le commerce de l'Angleterre. Paris, Sf., 2 vols in-12., 1 libra y 14 sueldos, $B$.

52.-CANTUEL, N., Remède contre la morsure du chien enragé. Paris, Sf, 1 vol in-8:, 10 sueldos, $B$. 
53.-CATALINA II de RUSIA, Instruction pour la commission chargée de dresser le projet d'un nouveau code de lois. San Petersburgo, 1770. in vol in-4..

54.-CATULLO, C. Val., Carmina. París, 1743, 1 vol in-12a .

55.-CÉRAM, M. de, Manuel Antisiphilictique. París, Sf, 1 vol in-12. , 2 libras y 10 sueldos, $B$.

56.-CERVANTES, M. de, El ingenioso hidalgo D. Quijote de la Mancha. Madid, Ibarra, 1780,4 vols in-4. .

57.-Code Matrimonial. SI. ni fecha, 1 vol in-4., 12 libras.

58.-Connaissance des poètes les plus célèbre. París, Sf, 2 vols in-12.', 2 libras, B.

59._CORNEILLE, P., Téâtre. Comentado por Voltaire. Ginebra, 1773, 8 vols in-4.

60.-COURAYER, A., Histoire du Concile de Trente. París, 1751, 3 vols in-4., 12 libras y 19 sueldos.

61.-COURTANVAUX, J., Journal de voyage. París, 1768, 1 vol in-4..

62.-CREBILLON, C., Lettres athenienses. París, 1776, 4 vols in- 8. , 4 libras y 16 sueldos, $B$.

63.-CHANGEUX, L., Traité des extrêmes. París, Sf, 2 vols in-12. , 2 libras y 12 sueldos, $B$.

64.-CHARDIN, J., Voyages en Perse et autres lieux de l'Orient. Amsterdam, 1711, 3 vols in-4. .

65.-CHICOURT, M., Description de six espèces de pets, ou six raisons pour se conserver la santé. Troyes, Garnier, Sf. 1 vol in-8., 1 libra y 8 sueldos, B.

66.-CHOISEUL-GOUFFIER, M. E., Voyage pittoresque de la Grèce. París, $1782,1 \mathrm{vol}$ in folio.

67.-DAVILA, A., Histoire des guerres civiles de France. SI ni fecha, 3 vols in-4:, 12 libras $B$.

68.-De l'homme et de la femme. París, Sf, 2 vols in-12, 6 libras, B.

69.-DELOLME, J. L., The Constitution of England. Londres, 1784, 1 vol in-8:, 16 libras. 
70.-Description et mémores sur la Lousiane. Paris, Sf, 2 vols in-12., 1 libra y 10 sueldos, B.

71.-Des maladies de poitrine ou Phtisie pulmonaire. Paris, Sf. 1 vol in-12:, 1 libra 12 sueldos, $B$.

72.-DESPRADES, A., Les quatre parties du jour à la ville. Paris, 1777, 1 vol in-12. Trad. a! francés de "ll Mattino", de G. Parini [Venecia, 1771].

73.-Deux histoires de la Floride, Paris, $S f, 2$ vols in-12.', 1 libra.

74.-Dictionnaire historique des Autheurs ecclésiastiques. París, 4 vols in-8., 6 libras y 16 sueldos, $B$.

75.-DOTTEVILLE, V., Les histoires de Tacite. París, 1780, 2 vols in-12:, 2 libras, $B$.

76.-DREGUET, F., Institution d'un prince. Paris, 1746, 1 vol in-4․, 5 libras.

77.-DRINKWATER, J., History of the Siege of Gibraltar. Londres, 1785, 1 vol in-4., 12 francos.

78.-DUBY, P. A., Recueil chronolorique des événements. Paris, 1786, 1 vol in folio.

79.-DUCLOS, Ch. P., Considérations sur les moeurs de ce siècle. París, 1751,1 vol in-12. .

80.-DUFRESNE SAINT-LEON, L. C., Etude sur le crédit public. Paris, 1784, $1 \mathrm{vol}$ in-8. . El autor era el liquidador del erario real.

81.-DUOT, A, Réflexions politiques sur les finances et le commerce. París, Sf, 2 vols in-4., 2 libras y 4 sueldos, B.

82.-ENCYCLOPEDIE ou Dictionnaire raisoné des sciences, des arts et des métiers, par une Société de gens de lettres. Paris, Panckoucke, 1782. Cuadernillos con los artículos de D. Diderot.

83.-Eléments généraux de police. París, Sf. 1 vol in-12, $\mathrm{B}$.

84.-ELOY, N. F., Dictionnaire historique de la medicine ancienne et moderne. Mons, 1778, 4 vals in-4?.

85.- ENGLET de FRESNOI, P., Disertations sur les apparitions et les songes. París, Sf, 6 vols in-12., 6 libras y 12 sueldos, $B$.

86. -EPICTETO, Le manuel. París, Imp. ${ }^{a}$ Didot l'aîné, 1782, 1 vol in-8?, Traducción al francés por F. Naigeon. 
87.- ERASMO, L'éloge de la folie. París, 1751, 1 vol in-8‥ Traducc. al francés por F. de Guendeville.

88. -ESOPO, Fabulae. Oxford, 1718, 1 vol in-8. .

89.-IDEM, Les fables de [...]. Ruán, 1785, 1 vol in-8..

90.-Esprit de L. Bourdaloue. París, Sf. 1 vol in-12.', 1 libra y 6 sueldos, B.

91.-Esprit de Fontenelle. Paris, Sf, 1 vol in-12., 1 libra y 6 sueldos, B.

92.-Esprit de Montiesquieu. Paría, Sf, 1 vol in-12., 1 libra y 6 sueldos, B.

93.-Esprit de Saint Evremond. París, Sf, 1 vol in-12., 1 libra y 6 sueldos, B.

94.-Esprit de Saint Réal. París, Sf, 1 vol in-12, 1 libra y 6 sueldos, B.

95.-ESQUILIO, Tragédies. París, 1770, 1 vol in-8., trad. al francés por A. Dacaut, 3 libras y 2 sueldos.

96. - Essai sur la decadence du commerce de l'Anglaterre. París, Sf, 2 vols in-12., 1 libra y 14 sueldos, B.

97.-Essai sur la puissance temporelle des Papes. París, Sf, 1 vol in-12, 1 libra, B.

98.-Essai sur l'éducation des jeunes Demoisselles. París, Sf, 1 vol in-8., 14 sueldos, $B$.

99.--EURIPIDES, Tragédies. París, 1782, 4 vols in-8 ${ }^{\circ}$, traducción al francés por P. Prévost.

100.-FABRIZIUS, Théologie de l'eau. SI no fecha, 2 vols in- $8^{\circ}$, 2 libras y 4 sueldos, $B$.

101.-FENELON, F., Les aventures de Télémaque. Paris, 1783, 2 vols in-4. 102.-FIELDING, $\mathrm{H}_{\text {, }}$ Amelia. Londres, 1752, 1 vol in-12..

103. - IDEM, History of Tom Jones. Londres, 1749, 2 vols in-12\%. 104.-FLECHIER, E., Oeuvres. Nimes, 1782, 2 vols in- $8^{\circ}$ de los 5 que constaba esta edición.

105.-FREDERIC II de PRUSSE, Anti-Machiavel ou essai de critique sur le Prince de Machiavel par [...], publié par Voltaire. La Haya, 1740, 1 vol in-8. .

106. - FRISI, P., Traité des rivières et des torrents. Paris, Sf, 1 vol in-4. , 5 libras y 10 sueldos, $B$.

107.-GAILLARD, G. H., Histoire de la rivalité de la France et de l'Angleterre. Paris, 1777,1 vol in-12\%. 
108.-GANNETÉ, H., Purification de l'air croupissant. París, Sf, 1 vol in-8. 1 libra y 14 sueldos, $B$.

109. - GIUSTINIANI, L., Memorie istoriche degli scrittori legali del Regno di Napoli. Nápoles, 1783, 3 vols in-4., 15 francos.

110.-GRANADOS, Fr. J., Tardes americanas, México, 1778, in vol in-8?.

111.-GRANTUEL, A., Remèdes contre la constipation. París, 1773, in-8., 1 libra y 10 sueldos, $B$.

112.-GRIFFER, D., Des preuves de la verité de l'histoire. Lieja, 1749, 1 vol in-12:, 1 libra, $B$.

113.-GUICCIARDINI, F.,Della istoria d'Italia, libri XX. Venecia, 1738, 2 vols in folio.

114.-HACOT, J., Anecdotes galantes ou le moraliste à la mode. París, $1760,1 \mathrm{vol}$ in $12{ }^{\circ}$.

115.-HENAULT, J. F., Abregé de l'histoire de France. París, Sf, 1 vol in-4.', 6 libras y 10 sueldos.

116.-HERMILLY, N., Histoire d'Espagne. París, 1751, 10 vols in-4. , 42 libras y 19 sueldos.

117.-Histoire de D. Iñigo de Guipúzcua [sic]. París, Sf, 2 vols in-12. , 1 libra y 14 sueldos.

118.-Histoire de la Californie. París, 1767,3 vols in-12., traducc. del inglés, 2 libras y 6 sueldos, $\mathrm{B}$.

119. - Histoire de l'Afrique, de l'Asie et de l'Amérique. París, Sf, 5 vols in-4.', 33 libras.

120. - Histoire de la conjuration de Portugal. París, 1689, 1 vol in-12. , 2 libras y 5 sueldos, $B$.

121.-Histoire de Scipion et d'Epaminondas. Paris, Sf, 1 vol in-12:, 1 libra y 12 sueldos, $B$.

122.-Histoire des femmes galantes de l'antiquité. París, Sf, 6 vols in-12。, 9 libras y 12 sueldos.

123.-Histoire des révolutión d'Espagne. París, 1724, 3 vols in 12. 3 libras y 16 sueldos, $B$.

124.- Histoire du pontificat de Paul V. París, Sf, 2 vols in-12. 1 libra y 8 escudos, B. 
125.-HOME, B., Essai sur le blanchissonement [sic] des toits. Paris, Sf, 1 vol in-12., 1 libra y 16 escudos, B.

126. - HOMERO, L'lliade et l'Odyssée. París, 1780, 5 vols in-8.', trad. y notas de P. J. Bitaube.

127.-HORACIO, Carmina. Paris, 1763, 1 vol in-12:.

128. - JANIN, Ch., Réflexions sur la mort subite et violente. París, Sf, 1 vol in-12., 12 sueldos, $B$.

129.-JUVENAL, Satirae. París, 1776, 1 vol in-12. . Ed. de A. Philippe.

130. - KEMPIS, T. de, De la imitación de Cristo. Madrid, 1734, 1 vol in-8?, traducción de J. E. Nieremberg.

131.-LABRUYERE, J. de, Les caractères. Paris, 1765, 1 vol in-4‥

132.-LA COMANDINE, Ch. de, Rélation abregée d'un voyage fait dans l'intérieur de l'Amérique méridionale. Paris, 1745, 1 vol in-8.'.

133. - L'Adamiste ou le jésuite insensib/e. Colonia, 1712.

134.-LADVOCAT, D., Tractatus de Conciliis in genere. Paris, Sf, 1 vol in-12., 1 libra y 12 sueldos.

135.-IDEM, Lettres sur les textes difficiles de l'Escriture Sainte. París, 1768,1 vol in-8., 1 libra y 8 sueldos, $B$.

136.-LA FONTAINE, J., Fables choisies. París, 1782, 2 vols in-8..

137. - L'Afrique de Macmol [sic]. París, Sf, 3 vols in-4. ${ }^{\circ}$, trad. al francés por A. d'Ablancourt, 7 libras y 10 sueldos.

138. - L'Alcoran des convulsionistes. Yprès, 1743, 1 vol in-8. .

139. - La petite poste debalisée [sic]. París, Sf, 1 vol in-12., 17 sueldos, B. 140.-LAPORTE, C., Anecdotes dramatiques ou collection de toutes les pièces de théâtre par ordre alphabétique. París, 1775,3 vols in-8:.

141.-LA ROCHEFOUCAULD, F. de, Réflexions ou sentences et maximes morales. Paris, 1778, 1 vol in-8. .

142. - L'art de corriger dans les enfants les difformités du corps. París, Sf, 2 vols in-8., 2 libras y 4 sueldos.

143.-L'art de péter. Essai théori-physique et méthodique à l'usage des personnes constipées. Westfalia, 1776, 1 vol in-12., 6 francos.

144.-L'art de vérifier les dates. Paris, Sf, 1 vol in folio, 49 libras y 4 sueldos. 
145.-L'art de vérifier les dates des faits historiques jusqu'en 1770. París, $1783-86,3$ vols in folio.

146. - La Sainte Bible. Edic. E. Carrières, 6 vols in-4․, 33 libras.

147.-LASSER, B., Théologie des Insects. París, sf, 2 vols in-8. , 4 libras y 8 escudos, B.

148.-LAVATER, J. C., essais sur la physiognomie. La Haya, 1781, 1 vol in-4.

149.-LEDIARD, F., Histoire navale de l'Angleterre. Lión, 1751, 3 vols in-4.', 8 libras.

150.-Le mauvais diner ou refutation du comte de Boulainvilliers. SI ni fecha, 1 vol in-8., 1 libra y 4 sueldos, $B$.

151.-L'ENFANT, G., Histoire des Conciles de Constance, Pise et Bâle. Lión, Sf, 6 vols in-4:, 15 libras y 6 sueldos.

152. - Le partage du lion de la fable vérifié par le Roi Très Chrétien [Luis XIV] dans celui de la monarchie d'Espagne. Colonia, 1701, 1 vol in-12.

153.-LEROUX, J. F., Dictionnaire comique, satyrique, critique, burlesque et proverbial. París, 1750,1 vol in-8..

154.-Les amours de Henri IV avec ses lettres galantes et les réponses de ses maîtresses. París, 1780,2 vols in $8^{\circ}$.

155.-Les impostures de l'histoire. París, Sf, 2 vols in-12.', 2 libras y 4 sueldos, B.

156.-LETI, F., Histoire de Philippe II. París, Sf, 6 vols in-12:, 6 libras y 12 sueldos, $B$.

157.-IDEM, Théâtre belgique. Amsterdam, 1691, 9 vols in-4ㅇ, 26 libras, B. 158.-IDEM, Vie de Isabel [sic], reine d'Angleterre. París, Sf, 2 vols in-12?, 2 libras y 16 sueldos, $B$.

159.-IDEM, Vie du Pape Sixte V. París, Sf, 1 vol in-4., 5 libras y 8 sueldos, B. 160.-L'homme considéré en lui-même. sl ni fecha, 1 vol in-12.', 14 sueldos, $B$. 161.-LINGUET, N., Canaux navigables de Paris. París, Sf, 1 vol in-12.?, 1 libra y 10 sueldos, $B$.

162.-IDEM, Le siècle d'Alexandre. París, 1765, 1 vol in-12.', 15 sueldos, B. 
163.-IDEM, Théorie du libelle. Réponse à la théorie du paradoxe. Paris, 1772,1 vol in-12., 1 libra y 16 sueldos, B.

164.-LOCKE, J., Le christianisme raisonnable. Amsterdam, 1740, 2 vols in-12., 3 libras y 6 sueldos, B.

165.-IDEM, Del Governo. Amsterdam, 1773, 1 vol in-8‥

166.-LOPEZ de AYALA, Ign., Historia de Gibraltar. Madrid, 1782, 1 vol in- 4. .

167.-MABLY, G. B. de, Entretiens de Phocion sur le rapport de la morale avec la politique. Paris, 1783, 1 vol in-18.

168.-MALLON, G., Essai politique sur le commerce. París, 1771, 2 vols in-8., 1 libra y 2 sueldos, $B$.

169.-MARCIAL, Val., Epigrammata. Paris, 1782, 2 vols in-8..

170.-MARCO AURELIO, Réflexions morales. Paris, 1772, 1 vol in-12..

Trad. de M. Dacier, notas de M. de Joly.

171.-MARMONTEL, J. F., Contes moraux. París, 1765, 3 vols in-8. .

172.-IDEM, Bélisaire. Paris, 1767, 1 vol in $8^{\circ}$.

173.-MARSOLLIER, J., Histoire de I'Inquisition et son origine. Colonia, 1693, 1 vol in-12., 10 francos.

174.-MARTIR, P. - GOES, D., De rebus oceanicis et ethiopicis. Colonia, 1574, 1 vol in-12., 2 libras y 3 sueldos.

175.-MAXIMO, Valerio, Sentences et maximes des romains. SI ni fecha, 1 libra y 6 sueldos, $B$.

176. - Métallurgie de Barba, avec les dissertations plus rares sur les Mines. 177.-MONTAIGNE, Essais. Paris, 1783, 3 vols in-8..

178.-MONTEQUIEU, Lettres. Paris, 1749, 1 vol in-12., 1 libra y 6 sueldos. 179.-MORLAIS, Abbé, Théorie du paradoxe. París, 1770, 1 vol in-12., 1 libra y 16 sueldos. Respuesta a este libelo en el n. ${ }^{\circ} 163$.

180.-NETTESHEIM, A. de, Sur la noblesse et excellence du sexe féminin. Leyden, 1726, 3 vols in-8.

181.-Office des Chevaliers de l'Ordre du Saint-Esprit. Paris, 1703, 1 vol, in-12:.

182.-Ordonnances de l'Ordre de la Toyson d'Or. París, 1723, 1 vol in folio. 
183.-PASCAL, B., Oeuvres Complètes. París, 1779, 5 vols in-8․

184.-PACQUET, L., Discours sur l'art de négocier. Paris, sf, 1 vol in-12.', 1 libra y 4 sueldos, B.

185.-PERRAULT, Dh., Histoires et contes du temps passé, avec des moralités. Paris, 1742, 1 vol in-12. .

186.-PETIT, J. L., Traité des maladies chirurgicales et des opérations qui leur conviennent. París, 1774-80, 2 vols, in-8..

187.-PHILIBERT, Abbé, Annales de la Société des soi-disants Jésuites ou recuil historique et chronologique. París, 1764-71, 5 vols, in-4.. El verdadero nombre del autor era A. Gazaignes; murió en Paris en 1803.

188.-PINDARO, Les Odes Pythiques. París, 1772, 1 vol in-8., traduc. al francés por J. Chabanon.

189.-POISSIER, Th., Essai sur les corps des baleines. París, Sf, 1 vol in-12., 1 libra y 20 sueldos, B.

190.-PREVOST, A. F., Histoire du chevaher des Grieux et de Manon Lescaut. París, 1753, 2 vols in-12. .

191.-PRIDEAUX, F., Histoire des Juifs. Amsterdam, 1728, 6 vols in-12.', 16 libras y 4 sueldos.

192.-Principes pour la lecture des Orateurs. París, Sf, 3 vols in-12., 3 libras y 6 sueldos, $\mathrm{B}$.

193.-Principes pour la lecture des Poètes. París, Sf, 2 vols in-12, 2 libras y 4 sueldos, $B$.

194.-PRISI, P., Traité des rivières et des torrents. París, Sf, 1 vol in-4ㅇ, 5 libras y 10 sueldos.

195.-PUFFENDORF, S., Le droit de nature et des gens. Amsterdam, 1734, 2 vols in-4:, traduc. de J. Barbeyrac.

196.-QUER, J., Flora española o historia de las plantas que se crian en España. Madrid, Ibarra, 1762-64, 4 vols in-4., con 189 láminas.

197.-RACINE, J., Oeuvres. Paris, 1783, 3 vols in-4․

198. - IDEM, Lettres. París, Sf, 2 vols in-12:, 1 libra y 8 sueldos.

199.-RAYNAL, G. T., Histoire philosophique et politique des établissements et du commerce des européens dans les deux Indes. Ginebra, 5 vols in- $8^{\circ}, 36$ libras, $B$. 
200.-Recherches philosophiques des Egiptiens et des Chinois. París, Ff, 2 vols in-12., 6 libras, $B$.

201.- Recherches sur la valeur des monnaies. SI ni fecha, 1 vol in-12\%, 17 sueldos, B.

202.-Recuell de machines approuvées par l'Académie de Sciences depuis son établissement jusqu'en 1754. París, 1735-77, 7 vols in fol.

203.--Recueil de pièces de médicine. Paris, Sf, 1 vol in-12. , 1 libra y 12 sueldos, B.

204.- Recueil de pièces philosophiques. SI ni fecha, 5 vols in-12:, 6 libras, B. 205.-Recueil de pièces sur la succession de Portugal. París, Sf, 1 vol in-12., 2 libras y 5 sueldos.

206. - Réflexions sur la fabrication des toiles peintes. Ginebra, Sf, 1 vol in-12., 1 libra y 10 sueldos, B.

207.-Relation de la Cour de Portugal sous Pierre II. Amsterdam, 1712, 1 vol in-12:, 2 libras y 5 sueldos, $B$.

208. - RETIF de la BRETONNE, N. E., Le paysan et la paysanne pervertis ou les dangers de la ville. Histoire récente. Paris, 1784, 2 vols in-12.. La obra entera constaba de 12 volúmenes.

209.-ROCHEFORT, J. de, Histoire des /sles Antilles. Lión, 1667, 2 vols in-12., 1 libra.

210.-ROUSEAU, J. J., Projet de paix perpétuelle. SI ni fecha, 1 vol in-12.", 1 libra, B.

211.-ROUSSELOT, N. A., Méthodes pour la guérison des cornes. París, Sf, 1 vol in-12., 8 sueldos, $B$.

212.-SABBATIER, A., Moeurs, coutumes et usages des anciens peuples. SI ni fecha, 1 vol in-4:, 5 libras y 8 sueldos.

213.-SAINT-REAL, Oeuvres. París, Sf, 8 vols in-12. 8 libras, B.

214.-SARPI, Fr. P., Histoire du Concile de Trente. París, 1751, 3 vols in-4., traduc. al francés por P. F. le Courayer.

215.-IDEM, Traité des bénéfices. SI ni fecha, 1 vol in-12., 1 libra y 1 sueldo, B.

216.-Satire menipée et le catholicon d'Espagne. Sf ni lugar, 2 vols in-12.', 2 libras, B. 
217. - SAVARY, Cl., Morale de Mahomet ou recueil des pures maximes du Coran. Paris, 1784, 1 vol in-18.

218.-SAVERIEN, A., Histoire des Philosophes modernes. París, 1773.

219.-SHAFTESBURY, A. A., Caracteristiques des hommes, opinions et temps. Ginebra, 1769, 3 vols in-8. .

220.-SOFOCLES, Tragédies. París, 1772, 2 vols in $12^{\circ}$, traduc. al francés por J. Dupuy, 4 libras y 7 sueldos.

221. - STERNE, L., Vie et opinions du chevalier Tristan Shandy. Paris, 1778, 1 vol in-18:.

222.-SWINBURNE, E., Voyage dans les Deux-Siciles. París, 1785-86, 4 vols in-8., traduc. al francés por J. B. de la Borde.

223. - TAUBERT, B., Des causes de la dépopulation. Sf ni lugar, 1 vol in-12:, 1 libra y 6 sueldos, $B$.

224.-Théâtre de la Grande Bretagne. Londres, 1715, 6 vols in fol, 130 libras y 4 sueldos.

225.-THEODORETO, Histoire Ecclésiastique de Eusebius. París, 1675, 4 vols in-4:, 11 libras.

226.-THEVAULt de CHAVElon, J. B., Voyage à la Martinique. París, 1763,1 vol in-4ㅇ, 3 libras y 5 sueldos, B.

227.-Traité de l'origine des cardinaux. Colonia, 1665, 1 vol in-12., 2 libras, B.

228. - Traité des vertus, des récompenses et des violences publiques. París, Sf, 2 vols in-12., 2 libras y 8 sueldos, B.

229.-TREVOUX, Dictionnaire de [...]. Paris, 1756, 8 vols in folio, 71 libras. 230.-TUCHER, Josias, Questions importantes sur le commerce. Paris, Sf, 1 vol in-12:, 12 sueldos, $B$.

231.-TWISS, R., Voyage à Portugal et Espagne. Berna, 1776, 1 vol in-4?

232. - VAN LOON, J., Histoire métallique des Provinces du Pays Bas. La Haya, 1736, 5 vols in folio, 31 libras y 5 sueldos.

233. - VARGAS, T., De stratagematis Societatis lesu. SI, 1641, 1 vol in-12․, 2 libras, $B$.

234.-VAYRAC, abbé, Etat présent de l'Espagne. París, 1721, 4 vols in-12\%, 3 libras y 2 sueldos. 
235. - VENABLES, Rob., The gentleman Angles. Londres, 1786, in-8. .

236.-VERTOT, P., Histoire de Malthe. París, 1737, 3 vols in-12., 10 libras y 6 sueldos.

237.-IDEM, Origine de la grandeur de la Cour de Rome. Lausana, 1745, 1 vol in-12:, 1 libra y 19 sueldos, B.

238.-IDEM, Révolutions de Portugal. París, 1722, 1 vol in-12., 1 libra y 10 sueldos, $B$.

239.-IDEM, Révolutions en Suède. París, 1695, 2 vols in-12., 1 libra y 10 sueldos, B.

240.-IDEM, Révolutions Romaines. París, 1727, 3 vols in-12.. , 4 libras.

241.-Vies des SS. PP. des Déserts. Amberes, 1714, 4 vols in-8. con figuras, 21 libras y 10 sueldos.

242.-VILLERS, Marquise de, Lettres. SI ni fecha, 1 vol in-12.', B.

243.-VIRGILIO, Pub., Opera. Ed. Louvre, 1 vol in folio, 20 libras.

244. - VOLTAIRE, Dictionnaire Philosophique. SI ni fecha, 1 vol in-8., 2 libras y 9 sueldos, $\mathrm{B}$.

245.-IDEM, Romans et contes. París, 1778,3 vols in-8. .

246. -IDEM, Le siècle de Louis XIV. Berlín, 1751, 2 vols in-12. .

247.-Voyage à l'Abisinie de Lobo. París, 1728, 1 vol in-4.', traduc. al francés de M. Legrand, 3 libras y 5 sueldos.

Como ya insinué más arriba, Heredia no se atuvo a ningún criterio al escribir esta lista de libros comprados por él en París; se trataba de un inventario informal, cuya función era meramente verificativa. Por eso puso los títulos de las obras y los nombres de sus autores en un desorden más bien selvático; nosotros los hemos colocado por orden alfabético. 


\section{NOTAS:}

SIGLAS: A.B.G. = Archivo Bardají de Graus (Huesca); A.C.C. = Archivo del Conde de Campomanes (Madrid); A.D.H.E. = Archivo del Duque de Hijar en Epila (Zaragoza); A.G.S. = Archivo General de Simancas; A.H.N. = Archivo Histórico Nacional de Madrid; A.R.S.I. = Archivo Romanum S.I. Roma.

(1) Se trata de D. Manuel Ventura de Figueroa, gobernador del Consejo de Castilla y Patriarca de las Indias. Por lo que se refiere a la ciudad de Valencia, en 1766 no estalló ningún motin como en Madrid y en otras localidades, y el «clamoreo» de los pasquines fue muy débil. algunos de estos pasquines pueden verse en A.C.C., 43-7. III, 82.

(2) R. OLAECHEA, Contribución al estudio del "motin contra Esquilache" (1766). Zaragoza, Homenaje al Dr. Frutos Cortés (1977) pp. 339-343; R. OLAECHEA, Nuevos datos históricobiográficos sobre el conde de Aranda, en "Miscelánea Comillas", t. 50 (1968) pp. 67-71. En el primero se estudia la pacificación nacional de 1766, y en el segundo la internacional de 1783, cabaimente 17 años después de la primera.

(3) Aranda a Heredia. París, 12 abril 1783. AHN, Estado, leg. 4220. Vide infra nota $n .^{\circ} 100$.

(4) Heredia daba al conde el título de "vuecencia", y Aranda trataba a su secretario de "vuestra señoria".

(5) OLAECHEA, Contribución... 0. c. pp. 236-241. Esta Junta Militar dirimió el llamado uproceso de La Habana", cuya fase final ofrece sorprendentes analogias externas con el juicio del 23-F.

(6) V. HEREDIA, Notas inéditas sobre los Heredia. Libro de población de Murcia. ABG, Ms. fols. 20 y 26.

(7) V. HEREDIA, Arbol de los Heredia y sus inclusiones de Hacienda, Patronatos y Llamamientos por donde [h]an venido. ABG; véase también GARCIA CARRAFFA, Diccionario heráldico y genealógico de apellidos españoles y americanos. Madrid (1954), t. 41, p. 60 y t. 46, p. 255.

(8) J. BORAO, Diccionario de voces aragonesas. Zaragoza (1884) p. 190. "CARLAN: Custos castri, seu illius Gubernator infeudatus, los cuales eran conocidos, fuera del condado de Ribagorza, con el nombre de castellanos. La Academia dice que carlán es el que, en algunas partes de la Corona de Aragón, tiene cierta jurisdicción y derechos en algún territorio».

(9) OLAECHEA, Nuevos datos... o. c. t. 49, p. 88; G. BORRAS, La Guerra de Sucesión en Zaragoza. Zaragoza, 1973.

(10) OLAECHEA, Nuevos datos... o. c. t. 49 , p. 88 n. 69.

(11) R. del ARCO, Memorias de la Universidad de Huesca. Huesca (1923) t. VIII, pp. 29 y 153. El claustro de la Universidad mostro una marcada simpatia por el archiduque austriaco.

(12) «Don Carlos, por la gracia de Dios Emperador de Romanos siempre augusto, Rey de Germania, de Castilla, de León, etc. etc.

Por quanto por parte de vos, Dn. Joseph de Heredia y Estanga, se me ha presentado que, aunque el Emperador mi Señor, por su Real Despacho expedido por el Consejo de Aragón, os confirio el Empleo de Comisario General de la Gente de Guerra de dicho Reyno, no se os ha formado vuestro Asiento, ni habéis entrado en el goze y percepción del sueldo que por este empleo os corresponde, assí por haver seguido el exercicio de la Campaña de aquel año, como por ser preciso que se os despache Título de Guerra, a fin de que os reputen los oficiales y soldados de mis tropas por tal Comisario General, que es la forma en que han obtenido este Puesto vuestros antecedentes. 
Suplicándome que, en esta consideración, sea servido mandar que se os [a]siente Plaza de él, con el sueldo que os corresponde, conzediéndoos el Despacho necessario; y [a]teniéndome a lo referido, y a to que me ha consultado el Consejo de Guerra: He resuelto elegiros y nombraros (como en virtud del presente Titulo os elijo y nombro) por Comisario General de la Gente de Guerra de mi Reyno de Aragón; dando y concediendo todas las honras, gracias, preeminencias y exempciones, que os tocan y pertenezieren, vien y cumplidamente, sin que os falte cosa alguna.

Por lo que mando se amtengan y guarden con la authoridad y demás requisitos a este Empleo anexos y correspondientes, con el qual es mi voluntad gocéis de sueldo, gages y emolumentos que estuvieren señalados en la Dotación.

Dado en Barcelona, a Veinte y ocho de Febrero de Mil setezientos y treze años. Yo La Reyna. Don Andrés de Molina y Zalduendo, Secretario de S.M., lo hice escribir por su mandamiento". A.B.G.

(13) V. HEREDIA, Arbol... o. c. fol. 8. Doña Jerónima era "hija de Gabriel Subiza y Teresa Portola, vecinos de Aolarjo, como se ve en la capitulación matrimonial. Barones de Abella, Buchols y San Román, vecinos de Alart, en el principado de Cataluña, a cuya Baronia tienen derecho los hijos y descendientes de esta casa, siempre que falte varón de aquella casa. Quien hoy la posee es don Antonio de Subiza y Codol, habitante de Barcelona».

(14) Ibidem. «El hijo mayor, Carlos, fue prebitero beneficiado de estas Parroquias [de Graus]; fue cura Rector de Serveto y de Grustán, y hoy racionero del templo de N. Sra. del Pilar, de la ración de la Casa Estanga, y vicario y oficial eclesiástico de esta Villa de Graus y su Partido.

El segundo hijo, José, casó en la vílla de Naval con Ana Loriente Alamán, sobrina del llmo. Obispo de Barbastro, don Carlos Alamán, del que era hermana su madren.

(15) Ibidem, fol. 9. Doña Antonia era uhija de Ignacio alamán y M. ${ }^{a}$ Antonia Cavero, vecinos de Naval. Le dieron en dote 4.000 sueldos jaqueses de contado. Fue sobrina del IImo. D. Carlos Alamán, hermano de su padre, obispo de Barbastro, colegial que habia sido en el Mayor de San Vicente de Huesca, canónigo, vicario general y juez de causas pías en la Catedral de Zaragoza, y antes vicario general y gobernador del Arzobispado de Tarragona.

Por muerte de su hermana, doña Ignacia, fue y es heredera universal de la casa y palacio de Naval, de sus Salinas y de distintos censales cargados a su favor, de manera que su dote en sus capitales, aihajas y dinero, asciende a unos 34.000 sueldos jaqueses".

(16) Ibidem, fols. 19-20. Los otros hermanos de Ignacio fueron: Antonio, "presbitero, heredero nombrado por su padre y como fideicomisario de la dicha su mujer doña Antonia»; Vicente, "colegial mayor en el dicho de San Vicente de Huesca y Alcalde de la Villa de Graus"; Ignacia y Raimunda, "monjas profesas en Santa Clara, de Barbastro, de la Orden de San Francisco"; Antonia, casada en Barbastro con don Pedro de Garcia de Aolva, caballero regidor perpetuo de dicha ciudad"; Manuela, "dama moza, que actualmente vive en su casa con el dicho Antonio, beneficiado de las Parroquiales de esta Villa de Graus, vicario y oficial»; y Francisco Javier, que "ingresó en la Compañia de Jesús".

"Los dichos [Juan Francisco Heredia y Antonia Alamán] poseen en Naval unas casas grandes, magnificas si se quiere, Palacio situado en la dicha villa de Naval, en la calle llamada de Marín. Item, una casa pequeña, contigua a la misma. Item posee esta casa el Salinar de Lanero, una plaza con doce eras de salinas. Item, otro salinar en la partida llamada de Iruelos, con otras doce eras de salinas, las cuatro encima de las diez y nueve de la casa Cavero, y las ocho a la parte de abajo del salinar que fue de dicho Cavero, y éstas confrontan con el barranco de Iruelos, senda que va al salinar y comunales de la misman. 
(17) S. LOPEZ NOVOA, Historia de la M.N. y M.L. ciudad de Barbastro y descripción geográfico-histórica de su diocesis. Barcelona, Riera (1861) t. II, p. 322.

(18) M. BARTLLORI, Vida alternante de Baltasar Gracián en la Compañia de Jesús, en "Archivum Historicum S. I.", t. 18 (Roma, 1949) pp. 48 y 50; A. ASTRAIN, Historia de la Compañia de Jesús en la Asistencia de España (7 vols). Madrid (1920) t. VI, pp. 20-21.

(19) J. A. FERRER BENIMELLI, Sucedió en Graus hace doscientos años. Zaragoza, Homenaje al Prof. Lacarra, 1968. Estudia documentatmente la expulsión de los jesuitas que vivian en Graus el año 1767.

(20) Véase el n. ${ }^{\circ} 117$ de la "Lista de libros", de Heredia.

(21) DEL ARCO, o. c. t. VIII, p. 21. Oscilación del alumnado universitario entre 1772 y 1786.

(22) IDEM, Memorias... o. c. t. IX, pp. 247-291.

(23) Ibidem, t. II, p. 80.

(24) C. CoRonA, José Nicolás de Azara. Zaragoza, 1948, p. 70.

(25) OLAECHEA, Nuevos datos... o. c. t. 49, p. 92 n. ${ }^{\circ} 81$.

(26) Ibidem, pp. 92-93.

(27) Fernán Núñez de Aranda. París, 2 febrero 1788. AHN, Estado, leg: 2847.

(28) DEL ARCO, o. c. t. VIII, p. 166. El subrayado es mío.

(29) Heredia a Floridablanca. París, 26 febrero 1787. AHN, Estado, leg. 3445, n. ${ }^{\circ} 24$. Vide infra nota $n .^{\circ} 158$.

(30) Aranda a Heredia. Madrid, 12 febrero 1784. A.B.G.

(31) Aranda a Floridablanca. París, 23 de noviembre 1783. AHN, Estado, leg. 4162. "Aprovechando el permiso que la bondad del Rey N.S. me ha acordado para ponerme a sus pies, y dar una vuelta a ver mis intereses caseros, cuento partir de aquí después de la Concepción. Puede V.E. escribir a don Ignacio de Heredia en mi ausencia».

(32) OLAECHEA, Nuevos datos... o. c. t. 50, pp. 76-77.

(33) Herrería a Aranda. Nápoles, 27 abril 1784. AHN, Estado, leg: 2847.

(34) Aranda a Heredia. Madrid, $1 .^{\circ}$ marzo 1784. A.B.G.

(35) Idem idem. Madrid, 26 enero 1784. Ibidem. "Eh bien, Mr. le Chevalier, Si no me engaño en cálculos, estaré ahi con mi mochila a mediados de mayo; me gusta mucho (la Novia) del ejercicio a pié, y le hace mucho bien, con lo que VS la presentará a Mr. Métras, y se irán del brazo a pasear por las Tuillerías".

(36) Aranda a Heredia. Madrid, 26 febrero 1784. A.B.G. Francisco González de Bassecourt, conde de Asalto, era teniente general y gran cruz de la Orden de Carlos Iil. De 1766 a 1769 fue ministro plenipotenciario de España en Suiza, y de 1773 a 1788 Capitán General de Cataluña. Murió en 1793; FLORIDABLANCA, Obras originales, Madrid, BAE (1912) t. 59 p. 289. "Sátira tercera. AI conde de Asalto, que siempre ha sido [una] calabaza, le protejo, porque además de ser cuñado de la Chomba, se me ha rendido desde que vine [de la embajada] de Roma, me ha hospedado en Barcelona, y ha hospedado a mi hermano, sobrinos y recomendados".

(37) Victorio de Navia y Bellet (1722-1784), capitán general de Valencia y consejero de Guerra, fue nombrado en 1781 ayo de los Infantes reales. Murió ese año de 1784. 
(38) Francisco Antonio de Lacy, conde de Lacy, estuvo de embajador de España en Suecia y Rusia; en 1779 fue nombrado capitán general de Granada, y en 1780 inspector general de Artillería. En 1789 sucedió al conde de Asalto en la capitanía general de Cataluña. Murió en 1792. Estos tres altos militares debian ser unos auténticos retablos, carcomidos de achaques.

(39) Aranda a Heredia. Madrid, $1 .^{\circ}$ marzo 1784. A.B.G.

(40) Véase los números $21,25,55,65,71,84,108,128,143,150,186$ y 203 de la "Lista de libros".

(41) Aranda a Heredia. Madrid, 5 febrero 1784. A.B.G. "Señor Dn. Ignacio: Me ha hecho reir la de VS, que he recibido este correo, y juzgo es del 23 del pasado, porque la fecha no debia de ser de estilo en el Colegio de San Vicente, y Cáthedra de Pilatos. Martinus contra Siétamo, como si viese a ese Duende, a quien Volante deseaba dar la tripa de Berwick. Buen torillo tendrá que capear con motivo de la Boda [mía], cuando en breves dias tendrá barro a mano para llevar la casa a sangre y fuego. Ya verá VS si me entiendo en elecciones [de mujeres], y tendrá mejor opinión de mín.

(42) M. LANZ CASAFONDA, Diálogos de Chinduiza. Oviedo, 1972.

(43) V. HEREDIA, Arbo/... O. c. n. ${ }^{\circ} 8$.

(44) J. CANGA ARGÜELLES, Diccionario de Hacienda (2 vols). Madrid (1833) t. I, p. 304.

(45) J. G. L. PIZARRO, Memorias (3 vols). Madrid (1894) t. I, pp. 187, 192 y 233.

(46) M. BARING, Darby y Joan. Barcelona, Janés (1942) p. 178. E subrayado es mio.

(47) J. A. de Llano a Azara. Parma, 26 enero 1772. apud OLAECHEA, Nuevos datos... o. c. $t$. 49 , p. 95 n. ${ }^{\circ} 95$.

(48) Juanta anual general de la sociedad anti-hispana. Biblioteca Nacional, Secc. Manuscritos, n. ${ }^{\circ} 18470$, fol. 25.

(49) EL CENSOR. Barcelona, Ed. Labor (1972), pp. 84-85 y 118.

(50) Roda a Azara. Aranjuez, 2 junio 1772. ARSI, Hist. soc. lib. 234, I, p. 306.

(51) J. CARO BAROJA, Feijó en su medio cultural, o la crisis de la superstición, em «EI P. Feijoo y su siglo" (3 vols). Oviedo (1966) t. l, pp. 153-86.

(52) R. OLAECHEA, El concepto de "exequatur" en Campomanes, en “Miscelánea Comillas", t. 45 (1966) pp. 17-18.

(53) M. MENENDEZ PELAYO, Historia de los heterodoxos españoles, ( 3 vols), Madrid (1881) t. II, p. 528.

(54) A. BALLESTEROS, Historia de España y su influencia en la Historia Universal. BarceIona (1929) t. V, p. 92; T. EGIDO, Sátiras políticas de la España Moderna. Madrid, Ed. Alianza, 1973.

(55) R. OLAECHEA, Politica eclesiástica del Gobierno de Fernando VI. Oviedo, 1981.

(56) IDEM, Nuevos datos... o. c. t. 49, p. 100 n. ${ }^{\circ} 109$.

(57) J. GOMEZ ARTECHE, Reinado de Carlos IV (3 vols). Madrid (1894) t. I, p. 95. Se emplea aqui el vocablo coetáneo de "nacionalista", y no "regionalista", porque las gentes aragonesas del XVIII aludian a "la nación aragonesa" al referirse a su región.

(58) Es el n. ${ }^{\circ} 152$ de la Lista de Heredia.

(59) Defense du droit de la Maison d'Autriche à la succession d'Espagne et de la verification du partage du lion de la fable. Colonia, 1703, IN-12.. Es una nueva edición del anterior. 
(60) R. OLAECHEA, El conde de Aranda y «el partido aragonés», Zaragoza, 1969.

(61) IDEM, Nuevos datos... o. c. t. 49, p. $100 \mathrm{n} .^{\circ} 110$.

(62) Expediente personal de Ignacio de Heredia. AHN, Estado, leg. 3445, 2.

(63) OLAECHEA, Contribución... o. c. pp. 314-339.

(64) Interpretación libre-o actualizada-de la Oda "Rectius vives, Licini» (lib. II, ep. 10), de Q. Horacio Flaco.

(65) J. CADALSO, Escritos autobiográficos y Cartas. Londres (1978) Ed. N. Glendinning y N. Harrison. pp. 12-19, 187, 202-203.

(66) "Crítico", equidistante del "timorato pusilámine" y del "revolucionario iluso».

(67) L. ARROYAL, Cartas politico-económicas al conde de Lerena. Madrid, Ed. Ciencia Nueva (1968) pp. 68 y 72; OLAECHEA, El concepto... 0. c. pp. 14-15.

(68) R. OLAECHEA, Anotaciones sobre la inmunidad local en el XVIII español, en "Miscelánea Comillas", t. 46 (1966) pp. 321-323; A. MESTRE, Asensio Sales; la actitud ilustrada de un obispo partidario de la Compañia de Jesús, en "Anales Valentinos", n. ${ }^{\circ} 17$, t. IX (Valencia, 1983) pp. 73-75. Denunciando las intromisiones de ambas potestades.

(69) Azara a Ronda. Roma, 23 noviembre 1769. Apud El espiritu de D. José N. de Azara descubierto en su correspondencia epistolar con D. Manuel de Roda (3 vols). Madrid (1846) t. I, p. 362.

(70) Heredia a Azar. Madrid, 20 diciembre 1769. A.B.G. El trozo de San Hilario está tomado del "Commentarium in Matthaeum", cap. 23. MIGNE, Patr. Lat., t. 9, cols. 1044-45.

(71) OLAECHEA, El concepto... o. c. pp. 132-33.

(72) IDEM, Nuevos datos... o. c. t. 49, p. 99 n. ${ }^{\circ} 107$.

(73) Pio VI a I. de Heredia. Roma, 18 setiembre 1779. A.B.G. Por medio del cardenal C. Rezzonico.

(74) M. GOMEZ CAMPILLO, El conde de Aranda en su embajada de Francia (1773-1787). Madrid (1945) pp. 13-15.

(75) OLAECHEA, Nuevos datos... o. c. t. 49 , p. $130 n .{ }^{\circ} 216$.

(76) Grimaldi a Heredia. Aranjuez, 26 junio 1773. AHN, Estado, leg. 3445, 2.

(77) Instrucciones de Grimaldi a Aranda. AHN, Estado, leg. 3457, 40; Aranda a Grimaldi. San Ildefonso, 14 agosto 1773. lbidem, leg. 3422. Acusando recibo de las Instrucciones; sólo la firma es de Aranda, el texto de la carta está redactado por Heredia.

(78) Azara a Roda. Roma, 7 julio 1773. Apud El espiritu... o. c. t. II, p. 429. "Me alegro de que al conde [de Aranda] le hayan dado gusto, en dejarle su secretario Heredia, y que a éste lo hayan hecho oficial de la Secretaría, porque al fín es nuestro paisano, y mi amigo desde la nínez".

(79) OLAECHEA, Nuevos datos... o. c. t. 49 , p. 132 n. ${ }^{\circ} 227$. Vide supra nota n. 62.

(80) Aranda a Grimaldi. Paris, 23 noviembre 1773. AGS, Estado, leg. 4590.

(81) Aranda a Moñiño. Fontainebleau, 25 octube 1773. AEER [Archivo de la Embajada Española en Roma. Madrid], leg. 338. "Muy Señor mío. Habiendo propuesto yo a este Ministerio, en virtud del oficio del Sr. Marqués de Grimaldi, el medio adoptado por el Rey N.S. [Carios III] para restituir al Papa los Estados de Aviñón y Benevento, y de que VSI se halla instruido, me ha respondido el Sr. Duque d'Aguillon que el Rey Cristianísimo lo habia totalmente aprobado, y mandado autorizar al Cardenal de Bernis [embajador de Francia en Roma] para que obrase de 
acuerdo con VSI, a quien remito copia de dicha respuesta para su noticia gobierno"; F. MASSON, Le cardinal de Bernis depuis son ministere (1758-1794). Paris, Plon (1844) pp. 229-235. Para la devolución de Benevento, posesión pontificia enclavada en territorio napolitano, Monino tuvo que verselas con el ministro Tanucci.

(82) Aranda a Moñino. Fontainebleau, 25 octubre 1773. AEER, leg. 338 . Original autógrafa.

(83) Heredia a Moñino. Fontainebleau, 25 octubre 1773. Ibidem.

(84) OLAECHEA, Nuevos datos... o. c. t. 49, pp. 149-167, 171-196. "Una intriga inocua y un plan de gobiernom.

(85) V. PALACIO ATARD, El tercer pacto de familia. Madrid, C.S.I.C., 1945; D. OZAMAN, Les origines du troisième pacte de famille, en "Rev. d'Hist. Diplomatique», t. 75 (París, 1967) pp. 307-340.

(86) Aranda a R. Wall. Varsovia, 16 marzo 1761. AGS, Estado, leg: 6853.

(87) FLORIDABLANCA, o. c. p. 258 n. ${ }^{\circ} 304$, p. 260 n. ${ }^{\circ} 314$.

(88) OlAECHEA, Nuevos datos... o. c. t. 50, pp. 39-40; FLORIDABLANCA, o. c. p. 260 n. ${ }^{\circ}$ 318-19.

(89) R. B. MORIS, The Peacemakers. New York, 1965. Analiza el despliegue diplomático que culmino en setiembre de 1783 , fecha de la paz de Versalles.

(90) Floridablanca a Aranda. Madrid, 2 enero 1783. AHN, Estado, leg. 4101. Responde a la de Aranda del 18 de diciembre, aprobando que haya enviado a Heredia a Londres.

(91) Heredia a Aranda. Calais, 20 diciembre 1782. AHN, Estado, leg: 4220.

(92) Heredia a Aranda. Londres, 15 enero 1783. Ibidem. "Desde que desterre las salsas tengo el estómago como un bronce, y digiero bien cuanto comou; Idem idem, Londres, 27 enero 1783. Ibidem. Que vuelve al hotel muy tarde en la noche y semiebrio, después de haber estado casi cuatro horas comiendo y bebiendo.

(93) Heredia a Aranda. Londres, 24 enero 1783. Ibidem; Idem eidem. Londres, 14 enero 1783. Ibidem. "Esta última semana he asistido a bailes, banquetes, y a una botadura de un barco de 74 cañones. Esto fue el 24 del pasado. Aún no he probado la salsa de tortugan.

(94) OLAECHEA, Nuevos datos... o. c. t. 50, pp. 42-43.

(95) FLORIDABLANCA, o. c. pp. 317-18.

(96) Vide supra nota $\mathrm{n}^{\circ} 3$.

(97) Floridablanca a Heredia. Madrid, 29 diciembre 1783. AGC, Estado, leg. 4633.

(98) Heredia a Aranda. Londres, 24 enero 1783. AHN, Estado, leg. 4220. "Esta no va de oficio, de miedo de que no piensen que V.E. y yo obramos de acuerdo en todo este negocion.

(99) M. HERNANDEZ, La paz de 1783 y la misión de Bernardo del Campo en Londres, en "Estudios de Hist. Moderna". Barcelona, 1950; Floridablanca a Heredia. Pardo, 12 febrero 1783. AHN, Estado, leg: $3445,2$.

(100) Heredia a Aranda. Londres, 18 febrero 1783. Ibidem, leg. 4220.

(101) Idem eidem. Londres, 2 abril 1783. loidem.

(102) Aranda a Heredia. Paris, 13 marzo 1783. Ibidem.

(103) Aranda a Heredia. Paris, 16 marzo 1783. Ibidem; DEL ARCO, o. c. t. VIII, pp. 39 y 48 . EI 12 de agosto de 1768 , Aranda habia sido nombrado doctor por la Universidad Sertoriana. Vide supra notas 3 y 41 . 
(104) J. PEREZ, Los movimientos precursores de la emancipación de Hispano-América. Madrid, Ed. Alhambra, 1977; E. ZUDAIRE, Don Agustin de Jáuregui y Aldecoa, Presidente, Gobernador y Capitán General del Reino de Chile. Pamplona, Inst. Princ. de Viana, 1978; IDEM, Análisis de la rebelión de Tupac Amaru en su bicentenario (1780-1980), en "Rev. de Indias", t. 40 (Madrid, 1980) pp. 13-80.

(105) OLAECHEA, Nuevos datos... o. c. t. 50, pp. 44-46.

(106) Aranda a Heredia. Paris, 12 abril 1783. AHN, Estado, leg. 4220. «Sr. Dn. Ignacio: Me ha llegado para VS la adjunta del signor Abate fratello suyo [Francisco Javier]. Esta va al vicecónsul de Calais, Mr Tellier, con prevención de que si VS hubiere pasado ya, le ponga otra cubierta para el Sr. Sanafé de La Hayan. F. J. Heredia a Aranda. Bolonia, 8 enero 1783. AHN, Estado, leg. $3445, n{ }^{\circ}$ 112. "Muy Excmo. Sr. mio: La alta protección y estima con que V.E. honra y favorece a mi hermano ignacio, y por él a toda la familia, son causa de que yo me tome la libertad de dirigirle por medio de V.E. la adjunta, pues creyendo obligación mía manifestarle mi consuelo y gozo al verlo destinado para una comisión tan decorosa e interesante, y no sabiendo por qué camino dirigirme, fundado en la benignidad de V.E., he excogido éste, como el mejor y más seguro.

"Suplico a V.E. perdone esta mi libertad, y que me haga el honor de contarme en el número de sus más apasionados servidores; y supuesto que para poco o nada valgo, desahogaré, en cuanto pueda, mi pasión rogando al Señor guarde y prospere la importante vida de V.E. los muchos años que le suplico». Escrito al margen, con letra autógrafa de Aranda, se lee: "Respondida a 4 de marzo".

(107) Heredia a Aranda. La Haya, 22 abril 1783. AHN, Estado, leg. 4220; GIGASSCHUBART, Lettres d'un diplomate danois en Espagne (1798-1799), en "Rev. Hispanique», t. 9 (París, 1902) pp. 413-414. Sebastián de Llano, conde de Sanafé, era hermano del ya citado "covachuelista” José Agustín de Llano, marqués de Llano y embajador de España en Viena (PIZARRO, 0. c. t. 1, 64-70, 76). Schubart conoció en Madrid a la viuda de José Agustín; anteriormente había visto en La Haya, en casa de D. Sebastián, un espléndido retrato de cuerpo entero- "La dama del papagayo"-que el pintor italiano R. Mengs habia hecho a "la mancheguita de guastata bellezza", como llamaba J. N. de Azara a esta dama de "herpética hermosura", cuyo cutis facial estaba estropeado por un inoportuno herpe.

(108) Floridablanca a Aranda. Madrid, 19 julio 1784. AHN, Estado, leg. 4162. Aprobando los gastos de Heredia en Inglaterra, desde el 18 de diciembre de 1782 hasta el 12 de mayo de 1783, que importaron 13.741 libras y 18 sueldos.

(109) OLAECHEA, Nuevos datos... o. c. t. 50, pp. 59-60.

(110) Aranda a Heredia. Paris, 28 abril 1783. AHN, Estado, leg. 4220.

(111) El tratado fue ratificado por Carlos III el 12 de setiembre en el sitio real de San lldefonso, y el portador de los documentos fue Juan Pomés, ayuda de cámara de Aranda.

(112) Carlos III a Aranda. San Ildefonso, 30 setiembre 1783. ADHE, sala V, leg. 18.

(113) Aranda a la condesa Aranda. Paris, 19 setiembre 1783. AHN, Estado, leg. 2863, 4. Minuta.

(114) Vide supra nota n. ${ }^{\circ} 111$.

(115) Antverpiae, nombre latino de Amberes, rica ciudad comercial, se usaba en lenguaje coloquial para indicar "albricias", "recompensas", "Sobresueldos», y también "exconjuros». 
(116) También el coronel J. Cadalso, que murió en el asedio de Gibraltar en febrero de 1782, estaba convencido de que no se llego a tomar esta plaza fuerte, porque hubo "tongo». Vide R. OLAECHEA, Esbozo psicológico de José Cadalso (1741-82). Bolonia, 1983; FLORIDABLANCA, o. c. p. 238.

(117) Aranda a Bernad. París, 19 setiembre 1783. ADHE, sala V, leg. 18.

(118) Vide supra nota $n .{ }^{\circ} 31$.

(119) Aranda a Heredia. Madrid, 19 enero 1784. A.B.G. "No les va mal el meneo a mis piernas, para mi regreso ahí con la compañia que no me imaginé a mi salida».

(120) OLAECHEA, Nuevos datos... o. c. t. 50, pp. 76-78.

(121) Aranda a Heredia. Madrid, 6 abril 1784. A.B.G. Para limitarme a uno de los ejemplos más "delicados", en esta carta decia el conde a Heredia, que ya estaban preparados los coches para emprender el viaje a París, y que ccuanto ocurra en el camino encima de los colchones irá a la salud de VS".

(122) Aranda a Heredia. Madrid, 23 febrero 1784. A.B.G. Esta carta, que se refiere a reformas de tabiques y otras obras en la embajada, está llena de alusiones y sobreentendidos picantes, sólo inteligibles para Heredia.

(123) Azara a Aranda. Roma, 28 julio 1784. AHN, Estado. leg. 2847. El cardenal de Bernis era embajador de Francia en Roma.

(124) Aranda a Heredia. Madrid, 19 febrero 1784. A.B.G.

(125) Aranda a Floridablanca. Paris, 4 setiembre 1784. AHN, Estado, leg. 4162.

(126) OLAECHEA, Nuevos datos... o. c. t. 50, pp. 50-51.

(127) Aranda a Floridablanca. Paris, 8 diciembre 1786. AHN, Estado, leg: 2850.

(128) Floridablanca a Aranda. Madrid, 14 junio 1786. AGS, Estado, lib. 178. Aprobando los gastos de suscripción a estas publicaciones periódicas.

(129) FLORIDABLANCA, o. c. pp. 289, 306 y 329-30; A. RUMEU DE ARMAS, Ciencia y Tecnologia en la España llustrada. La Escuela de Caminos y Canales. Madrid, Ed. Turner, 1980; A. J. PITARCH-N. DALMASES, Arte e industria en España, 1774-1907. Barcelona, Ed. Blume, 1982.

(130) E. ALVAREZ LOPEZ, A. J. Cavanilles. Ensayo biográfico-crítico, en "Anales del Jardian Botánico de Madrid", t. 6 (Madrid, 1946) pp. 1-64; E. BALAGUERAS QUESADA, Una conferencia del Doctor Cavanilles en la Academia de Ciencias de París, Ibidem, pp. 82-84. Otros pensionados por el rey de España, que estudiaban entonces en Paris, eran: Segismundo Malats (Veterinaria), Eugenio Izquierdo e Ignacio Luzuriaga (Ciencias Naturales).

(131) F. LOPEZ, Juan Pablo Forner et la crise de la consciense espagnole au XVIII siècle. Burdeos (1976) p. 96. A. MESTRE, Historia, fueros y actitudes politicas. Mayans y la histoirografia del XVIII. Valencia, 1970, pp. 430-431.

(132) A. CIORANESCU, Cartas de A. J. Cavanilles a José Viera y Clavijo. Santa Cruz de Tenerife, 1981. Véase en la "Lista de Libros", los n. ${ }^{\circ} 27,28,33,47,49$ y 196.

(133) F. LOPEZ, o. c. pp. 347-360.

(134) Floridablanca a Heredia. Madrid, 19 enero 1784. AHN, Estado, leg. 4096. Por ausencia de Aranda, en Madrid, Heredia estaba entonces al frente de la embajada española en París.

(135) Floridablanca a Heredia. Pardo, 24 marzo 1784. Apud F. LOPEZ, o. c. p. 359 n. ${ }^{\circ} 77$. "Observaciones sobre el artículo "España" de la Nueva Enciclopedia, traducidas al castellano por D. Mariano Rivera, Madrid, 1784. 
(136) F. LOPEZ, o. c. pp. 364-473; I. URZAINQUI - A. RUIZ PEÑA, Periodismo e llustración en Manuel Rubin de Celis. Oviedo (1983) p. 107.

(137) J. CASO GONZALES, Prólogo al libro citado de I. UZAINQUI y A. RUIZ de la PEÑA, p. XII.

(138) Aranda a Vergennes. Paris, 12 octubre 1785. AGS, Estado, leg. 4636. "Les excès de cet auteur ne rappellent que trop naturellement ceux auxquels se livrent tous les jours les écrivains français contre la Nation Espagnole. II semble que tout leur soit permis contre elle; ils en font leur jouet; ils l'insultent sans cesse avec une affectation et un acharnement dont aucune autre Nation n'offre d'exemple. Qu'a-t-on dû penser dans toute l'Europe, en voyant un auteur comme le Sieur Masson, consigner impunement dans un ouvrage tel que l'Encyclopedie des outrages contre l'Espagne?. Je net parle que de celui-là, parce qu'il séroit trop long de citer tous les autres [...]. Ceci me paroît mériter de la part de V.E. des refléxions sérieuses».

(139) Aranda a Floridablanca. París, 28 noviembre 1785. Ibidem.

(140) J. A. FERRER BENIMELLI, El conde de Aranda y su defensa de España. Refutación del «Viaje de Figaro a España». Madrid-Zaragoza, 1972.

(141) Ibidem, pp. 87-146.

(142) La carta de Aranda fue publicada integra por el "Journal de París", N. ${ }^{\circ} 318$, lunes 14 de noviembre de 1785, PP. 1309-1311. AGS, Estado, leg: 4636; FERRER BENIMELLI, El conde de Aranda... o. c. pp. 64-68.

(143) GOMEZ CAMPILLO, o. c. pp. 115-116. Tanto este autor, como Ferrer Benimeli, que le sigue en este punto concreto, no reproducen íntegro, sino la primera parte del largo despacho que Aranda dirigió a Floridablanca el 28 de noviembre de 1785.

(144) Aranda a Floridablanca. París, 28 noviembre 1785. AGS, Estado, leg. 4636.

(145) Ibidem.

(146) Ibidem. Reproducido sólo en parte por GOMEZ CAMPILLO.

(147) Aranda a Floridablanca. Paris, 17 febrero 1786. AGS, Estado, leg. 4636.

(148) FERRER BENIMELI, El conde de Aranda... o. c. p. 71.

(149) OLAECHEA, Nuevos datos... o. c. t. 49, p. 78 n. ${ }^{\circ} 22$.

(150) Floridablanca a Aranda. Pardo, 6 marzo 1786. AGS, Estado, leg. 4636. Este párrafo es una sintesis de lo que más por extenso le decía el ministro en su carta del 31 de diciembre de 1785, y reproduce GOMEZ CAMPILLO, o. c. pp. 117-118.

(151) Floridablanca a Aranda. San Ildefonso, 9 agosto 1784. AGS, Estado, leg. 4633.

(152) Floridablanca a Azara. Aranjuez, 29 abril 1788. ARSI, Hist. Soc. lib. 234, II.

(153) Aranda a Floridablanca. Burdeos, 30 octubre 1786. AGS, Estado, lib. 177.

(154) Idem eidem. París, 26 enero 1787. Ibidem, lib. 178.

(155) Floridablanca a Aranda. Pardo, 12 febrero 1787. Ibidem; Aranda a Floridablanca. París, 26 febrero 1787. lbidem, leg. 4637; Carlos III a Luis XVI. Pardo, 12 febrero 1787. AHN, Estado, leg. 2850. Que Aranda deja la embajada y le sucederá el conde de Fernán Núñez; M. VILLARRUTIA, Fernán Núñez, el embajador. Madrid, 1931.

(156) Fernán Núñez. París, 22 setiembre 1788. AHN, Estado, leg: 2847.

(157) Azara a Aranda. Roma, 10 octubre 1781. Ibidem. "No hay en el mundo convento más recoleto y bien guardado que el de España. Dios lo bendiga, que es bien grande, desde los Pirineos al morro de Gibraltar. Yo no sé por qué no nos Ilamamos, V.E. fray Aranda, y yo fray Azara». 
(159) Idem eidem. Roma, $10^{\circ}$ agosto 1787. lbidem.

(160) Aranda a Azara. Paris, 28 agosto 1787. Ibidem.

(161) OLAECHEA, Nuevos datos... o. c. t. 50, p. 87.

(162) Heredia a Floridablanca. Paris, 26 febrero 1787. AHN, Estado, leg. 3445, 24.

(163) Floridablanca a Heredia. Pardo, 17 marzo 1787. Ibidem, 26; P. DURAN, Elogio a la vida de D. Domingo Iriarte, en "Rev. Hispanique», t. 39 (Paris, 1917) pp. 313-390.

(164) V. HEREDIA, Arbol... ०. c. n. ${ }^{\circ} 8-9$. El barón murió el 14 de julio de 1811, dejando un hijo llamado Pablo.

(165) Capitulaciones matrimoniales, por el notario Antonio Olbés. Ateca, 3 de mayo de 1786. A.B.G.

(166) Pablo de Heredia y Godino ingresaría un dia en la Orden de Carlos III. Vicente de Herdia y Josefa Godino, tuvieron además una hija, Antonia, que en 1817 se casaría en Graus con elsenescente Vicente Bardaji Azara, sobrino del citado J. N. de Azara, y hermano del cardenal Dionisio Bardaji, y del embajador y politico Eusebio Bardaji, todos ellos naturales de Graus.

(167) J. A. FERRER BENIMELI, El conde de Aranda y "el frente aragonés" en la Guerra contra la Convención de Francia (1793-95). Zaragoza, 1967.

(168) Ordenes del principe de Castelfranco a Vicente de Heredia, de sacar de la cárcel de Graus a los sospechosos de colaborar con los franceses. Jaca, 26 mayo 1793. A.B.G. Orden del cuartel general de proveer mil raciones. Huesca, 4 agosto 1703. A.B.G.; Orden del príncipe de Castelfranco, de relevar con quinientos hombres a los segadores. Jaca, 29 julio 1793. A.B.G.

(169) Orden del cuartel general del 16 de junio de 1794. Ibidem.

(170) Orden del 31 de julio de 1794. Ibidem.

(171) Orden de ejecutar una leva general en el país, de ochocientos hombres, para la defensa de la frontera, hasta que la nieve cierre los Puertos. Jaca, 20 octubre 1794. Ibidem.

(172) M. GOMEZ URIEL, Biblioteca nueva de autores aragoneses (3 vols). Zaragoza (1885) $t$. II, p. 7.

(173) Papeles del A.B.G.

(174) Vide supra nota $n .{ }^{\circ} 164$.

(175) Papeles del A.B.G.

(176) Floridablanca a Aranda. S. IIdefonso, 6 agosto 1787. AGS, Estado, leg. 4637. "Llego aquí nuestro Don Iñigo de Heredia, siempre el mismo. He tenido el gusto de abrazarlen.

(177) Floridablanca a Múzquiz. San Ildefonso, 22 agosto 1783. AHN, Estado, leg. 3445, n. $^{\circ}$ 18. Vide supra notas $n .^{\circ} 34,36,96$ y 98 , sobre el propósito de Heredia de volver a España.

(178) Floridablanca a López de Lerena. Pardo, 17 marzo 1787. AHN, Estado, leg.3445, n. ${ }^{\circ}$ 26. No sabemos-documentalmente-si Heredia envió la lista de sus libros a Bilbao o a Madrid, a título de verificación y comprobante, pero parece que fue asi, a juzgar por la precaución que tuvo de señalar con una $B$ mayúscula cada uno de los libros que no estaban encuadernados.

(179) MENENDEZ PELAYO, o. c. t. III, p. 255; M. DEFOURNEAUX, L'Inquisition espagnole et les livres français au XVIII siècle. París, (PUF, 1963).

(180) Ceballos a Bardaji. Aranjuez, 21 febrero 1801. A.B.G. «El Rey se ha servido conceder a VS el permiso que solicita, para que pueda pasar en Aragón algunos dias con su familia, pero 
en atención a los motivos que de su R.O. le tengo insinuados, espero que usará VS con prudencia de esta concesión, y se detendrá lo menos que pueda.

Con arreglo a los deseos de VS, he pasado también, con comunicados, las correspondientes ordenes al Ministerio de Hacienda, a fin de que las traslade inmediatamente a la Aduana de Barcelona, para que no detengan a VS en aquella Aduana, y que se selle y precinte su equipaje, para su examen en Madrid"; V. LLEDO, D. Eusebio Bardaii Azara (1766-1844). Vida de un político y diplomático del siglo XIX. Madrid, 1982.

(181) Cavanilles a Floridablanca. Paris, 22 setiembre 1789. AHN, Estado, leg. 3022, 7. Anuncia su llegada de Francia antes que el duque del Infantado, y solicita que se le facilite en la aduana el registro de su equipaje, formado por muchos baúles y cajones.

(182) Una libra equivalía a 4 reales (o una peseta); y un real valia 5 sueldos.

(183) D. d'OBERKIRCH, Memoires. Paris, Mercure de France (1979) pp. 391-394.

(184) Ibidem, p. 394. "Una cosa muy extraña y digna de estudio, pero muy verdadera, es lo mucho que este siglo, el más inmoral que ha habido, el más incrédulo, el más filosóficamente fanfarrón, se vuelve al final no hacia la fe, sino hacia la credulidad, la superstición y el amor a lo maravilloson.

(185) J. A FERRER BENIMELI, El conde de Aranda y la Real Sociedad Económica Aragonesa de Amigos del País. Zaragoza, 1978. 